\title{
A Sociologia e a Sociologia Política em DADOS*
}

\author{
André Botelho ${ }^{1}$ \\ Lucas Correia Carvalho ${ }^{1}$ \\ ${ }^{1}$ Universidade Federal do Rio de Janeiro (UFRJ), Rio de Janeiro, RJ, Brasil. E-mail: \\ andrebotelho@digirotas.com.br
}

\section{DENTRO E FORA DA REVISTA DADOS}

T ada trivial no universo científico brasileiro, especialmente na 1 área dita das humanidades, a comemoração dos cinquenta anos de publicação de um periódico científico, como em 2016 ocorreu com DADOS - Revista de Ciências Sociais. Criada no âmbito do antigo Instituto Universitário de Pesquisas do Rio de Janeiro, da Universidade Candido Mendes (IUPERJ-UCAM) e mantida pela sua nova versão institucional Instituto de Estudos Sociais e Políticos, da Universidade do Estado do Rio de Janeiro (IESP-UERJ), a DADOS, através das últimas cinco décadas, tanto testemunhou mudanças significativas na sociedade brasileira, e noutras em escala global, como protagonizou mudanças fundamentais no campo das Ciências Sociais. Uma forma de comemorar este verdadeiro feito é certamente discutir as contribuições que se desenham em suas páginas e a partir delas. Nossa proposta, ao fazê-lo, é contribuir para a continuidade de nossas pesquisas sobre a história das Ciências Sociais contemporâneas em chave cognitiva alternativa à tradicional versão institucional, que prevaleceu décadas atrás na forma de contar a história das nossas disciplinas (Botelho,

\footnotetext{
* Agradecemos a Breno Bringel, a Antonio Brasil Jr. e a Maurício Hoelz a interlocução na realização deste artigo.
}

DADOS - Revista de Ciências Sociais, Rio de Janeiro, vol. 60, n3, 2017, pp. 703 a 749. 
2012, 2013, 2015; Bastos e Botelho, 2010; Botelho e Carvalho, 2011; Carvalho, 2015). Almeja-se também adensar e qualificar o conhecimento da sociologia política (Botelho, 2007, 2012, 2014) como parte crucial da experiência científica e intelectual das ciências sociais.

É a primeira vez que ensaiamos, nesse sentido, uma análise das nossas Ciências Sociais inspirada em ideias sobre a dinâmica da diferenciação funcional da Sociologia de Niklas Luhmann. Não se trata, porém, de uma aplicação direta da teoria dos sistemas, tampouco de uma discussão sobre o sistema da ciência da sociedade (Luhmann, 1996; 2007). Trata-se, ainda, de uma chave geral de leitura dos dados da pesquisa que nos permite pensar, principalmente, a complexidade e a autodiferenciação trazidas pelo aumento da especialização disciplinar da Sociologia tal como figurada nas páginas da revista DADOS nos últimos cinquenta anos. E isso a partir de outras distinções que não as tradicionalmente (e quase mecanicamente) associadas a fatores "externos" ao plano cognitivo - ou seja, como se a produção que aqui tratamos se constituísse em mero reflexo de processos que supostamente correriam externamente a ela, decorrentes, por exemplo, da modelagem dos interesses dos seus praticantes ou da sua lógica institucional própria. A chave luhmanniana proposta permite-nos ver como esta complexidade é em grande parte estruturada pela tradição de pesquisa da sociologia política no conjunto da coleção analisada, especialidade mais recorrente nela. Assim, a despeito da crescente opacidade interna do subsistema da Sociologia, é possível ainda gerar imagens mais integradas do universo em questão numa chave cognitiva, e não só em termos restritivamente institucionais.

Ademais, essa leitura permitiu, ainda, pensar a segunda especialidade mais recorrente identificada na coleção da revista DADOS, a de pensamento social e político, como uma espécie de autodescrição deste universo - hipótese já aventada anteriormente para uma nova inteligibilidade do papel cognitivo desta área de pesquisa para as Ciências Sociais praticadas no Brasil (Botelho, 2006). Daí que, como veremos adiante, tenhamos distinguido sociologia política como "campo" (englobando suas interfaces com outras especialidades) de sociologia política tout court. Como na coleção Sociologia de DADOS as relações sociais são interpretadas sobretudo em termos de relações de poder, a distinção se impôs como recurso analítico justamente para não inflacionar ou supervalorizar a sociologia política, mas, antes, para controlar a tendência a sua colonização que já aparece como um dado nos 
artigos da revista. Quase parafraseando Luhmann, poderíamos dizer que a distinção proposta permitiu-nos assinalar o movimento simultâneo de diferenciação que a sociologia política assume em relação ao seu "ambiente" (a coleção Sociologia de DADOS), como uma especialidade entre outras, e de modificação que acarreta aos ambientes como um todo, já que ela gera ressonâncias nas outras especialidades da Sociologia, que a absorvem de acordo com os seus próprios códigos e programas.

Ambas as "sociologias políticas" têm desenvolvimentos até certo ponto convergentes: há um contínuo decréscimo na produção da sociologia política, enquanto "campo" e especialidade, até os anos 2000, mas com sinalização de retomada de crescimento no decênio 2010 em curso. Ou seja, os dados nos sugerem que a crescente especialização da área da Sociologia se dá concomitantemente a uma diversificação interna ao "campo" da sociologia política que culmina, nos anos 1990, numa profunda especialização da área da Sociologia e numa significativa diminuição de publicações consideradas do "campo" da sociologia política.

A perspectiva luhmanniana parece ser heuristicamente útil em mais um sentido: para o autor alemão, a teoria só existe em referência a uma ontologia da diferença e da relação, que se contrapõe a uma ontologia mais tradicional, de caráter substancialista. Ao acompanhar as mutações do universo empírico de DADOS, foi preciso compreender as diferentes relações internas e externas à própria área da Sociologia, e como elas compõem ou deixam de compor entre si modos de comunicação que moldam, de maneira muito contingente, a configuração do sistema de publicação em determinado momento. Ainda que reconheçamos que todo recorte empírico já é também uma seleção, esforçamo-nos em apresentar o universo de publicações em seu dinamismo, dissolvendo essências estáticas e identidades disciplinares em relações e diferenças de modo a melhor circunscrever - apenas indicativamente - as perspectivas teóricas, aportes metodológicos e temas que percorreram esses cinquenta anos da revista DADOS. As linhas de desenvolvimentos cognitivos que nos pareceram cruciais na sua coleção de artigos de Sociologia são esboçadas a seguir. Apresentamos, em primeiro lugar, o universo da pesquisa e as convenções principais da nossa interpretação - esperamos - devidamente justificadas e, em segundo lugar, os dados sobre a coleção Sociologia de DADOS - Revista de Ciências Sociais. 


\section{O UNIVERSO DA PESQUISA}

A coleção da revista DADOS considerada na pesquisa é composta por 926 artigos publicados entre o volume 1, do segundo semestre de 1966, até o volume 59, número 1, de 2016. Desse total, 359 artigos foram identificados, a princípio, com a área da Sociologia ${ }^{1}$. Como em todo trabalho de classificação, também neste, os resultados são parciais e não deixam de expressar relativa arbitrariedade, ainda mais porque não pudemos levar em conta, por exemplo, nem autoclassificações por parte dos autores ou da editoria da revista, nem para textos convencionais, uma vez que é somente a partir do seu volume 6, de 1968, que a DADOS passa a publicar os resumos dos artigos, enquanto as palavras-chave aparecem somente a partir do volume 39, em 1996. Assim, operamos com dois critérios principais para classificar o universo da Sociologia dentro da coleção. Um critério formal foi a área de formação no doutorado do autor ou do autor principal, no caso de artigo coletivo. O segundo critério empregado decorreu da leitura dos resumos e das palavras-chave, sempre que possível, ou da íntegra dos artigos, sempre que inevitável, na busca de identificá-los com uma das especialidades correntes da Sociologia (como, por exemplo, teoria sociológica, estratificação social, sociologia do trabalho, sociologia econômica, entre outras).

Esses dois critérios, contudo, foram empregados de modo integrado, uma vez que, em alguns casos, embora a formação do autor tenha se dado em área diferente da Sociologia, seu artigo considerado versava sobre temas e debates próprios a esta disciplina. Dois exemplos podem ilustrar de saída o emprego associado desses critérios: Bolívar Lamounier, com Ph.D. em Ciência Política pela Universidade da Califórnia, Los Angeles, em 1974, e mais do que isso, reconhecidamente ator da própria institucionalização da Ciência Política no Brasil, publicou, no segundo semestre de 1966, artigo sobre a abordagem funcionalista na sociologia política, sendo por isso classificado dentro da disciplina Sociologia. Outro exemplo, em sentido inverso, refere-se ao artigo "Depois do Milagre" de Gláucio Ary Dillon Soares (1978), também expoente na institucionalização das Ciências Sociais no Brasil com doutorado em Sociologia na Washington University in St. Louis, Missouri, em 1965. Neste artigo, o autor analisa como a queda dos índices econômicos implicou uma crescente desconfiança por parte de uma expressiva parcela da população e pelo partido governista em relação ao governo militar, avaliando como reduzidas as possibilidades 
de mudança quanto à ingerência estatal sobre a sociedade e à reorientação da tecnocracia burocrática no que tange ao regime político. Apesar da formação do autor em Sociologia e de sua reconhecida contribuição para essa área, a abordagem desse artigo, centrada, sobretudo, nas mudanças institucionais, levou-nos a não incluí-lo em nosso estudo, entendendo que o mesmo se adequa melhor à área de Ciência Política. Problemas desse tipo vêm sendo verificados em outros sistemas de classificação da produção bibliográfica dos cientistas sociais brasileiros (Botelho, 2012) em função das suas trajetórias acadêmicas e intelectuais não lineares, do caráter tardio (em relação à Sociologia) da institucionalização da Ciência Política no Brasil e do próprio contexto particular das Ciências Sociais em geral no país, cuja história tem favorecido relativa inter-relação entre antropologia, sociologia e ciência política, como expressa, ademais, o protagonismo da Associação Nacional de Pós-Graduação e Pesquisa em Ciências Sociais (ANPOCS) nos últimos quarenta anos.

É importante observar que, não por acaso, os exemplos destacados dizem respeito justamente a duas áreas disciplinares - a Ciência Política e a Sociologia - que vêm recebendo destaque na revista desde o início, ainda que sua política editorial venha privilegiando a interdisciplinaridade (Campos, Feres Jr. e Guarnieri, 2016). Igualmente importante é o fato de aqueles casos também se referirem a uma subárea da Sociologia, a sociologia política, que, com frequência, aparece intimamente relacionada à Ciência Política. Neste aspecto, porém, o caso DADOS segue tendências internacionais mais amplas, que cabe assinalar com atenção desde já. Como Botelho (2014) mostrou para o contexto internacional, o relacionamento da sociologia política com a Ciência Política, mais do que com a própria Sociologia, há tempos tem ocupado parte importante das reflexões dos especialistas. Por exemplo, entre aqueles ouvidos nos simpósios realizados pela Seção de Sociologia Política da American Sociological Association (ASA), cujas respostas foram publicadas em seu boletim oficial, Political Sociology: States, Power and Societies, no verão de 2008; ou, como em seu número anterior, do outono de 2007, no simpósio "Great books and articles every political sociologist should know". Esforços recorrentes deste tipo levaram a Seção de Sociologia Política da ASA a sistematizar e aperfeiçoar a série de discussões encaminhadas em suas newsletters ao longo de décadas, para tornar público, em 2005, o significativo projeto editorial The Handbook of Political Sociology, como assinalam seus organizadores no prefácio (Janoski et al., 2005:xiii). Muito importante ainda notar que o 
próprio Comitê de Pesquisa em Sociologia Política da International Sociological Association (ISA), fundado em 1960, está presente até hoje, desde 1970, simultaneamente na International Political Science Association (IPSA).

Pela importância particular que a sociologia política assumiu na presente pesquisa, vale indicar outras situações empíricas enfrentadas que vão nos ajudar a explicitar os critérios de classificação adotados para observá-la nas páginas de DADOS. Assim, em alguns casos, optamos por identificar dupla filiação disciplinar dos artigos, por exemplo, como no debate entre Fernando Henrique Cardoso, Fábio Wanderley Reis e Simon Schwartzman em torno do artigo deste último sobre as eleições de 1974. Eleições, como se sabe, constitui tema central da Ciência Política, mas, no caso destacado, foi abordado, sobretudo, a partir da relação Estado-sociedade, problemática crucial, por sua vez, da agenda de pesquisa e mesmo da identidade cognitiva da sociologia política. Como o exemplo acima mobilizado já indica, a pesquisa deixou claro que precisávamos operar com uma compreensão matizada da sociologia política para efeitos de classificação dos artigos.

Os três exemplos a que recorremos nos lançam, já de saída, ao centro dos problemas metodológicos mais importantes envolvidos nesse tipo de classificação qualitativa que estamos propondo para entender os artigos publicados nas páginas da revista DADOS. Além disso, ilustram bem o sentido empírico o nosso "corpo a corpo" com os artigos, que está na base do trabalho de classificação empreendido. Mas, principalmente, os exemplos já mostram aquela que talvez seja a característica distintiva da coleção de sociologia da revista: o notável interesse dos artigos de diferentes subáreas ou especialidades da Sociologia em tratar as relações sociais em termos, sobretudo, de relações de poder. Essa tendência constante observada ao longo das cinco décadas de vida da revista expressa, no limite, uma posição definida no debate sobre a inteligibilidade da vida social e da própria identidade da Sociologia, e pode ser relacionada a, pelo menos, dois fatores principais.

O primeiro, mais paroquial, vincula-se à configuração particular do universo empírico do estudo, uma vez que a concentração de artigos nas áreas da Ciência Política e da Sociologia, assim como, especialmente, a promoção do diálogo entre elas, não deixa de expressar também a especialização disciplinar institucional e cognitiva própria do antigo IUPERJ e, a partir de 2010, do IESP-UERJ, as instituições responsáveis 
pela publicação e, ao menos em parte, pelas políticas editoriais da revista - algo perceptível no caso da Ciência Política, conforme o artigo de Lynch $(2016)^{2}$. Pesquisando as duzentas primeiras teses de doutorado defendidas no antigo IUPERJ entre 1987 e 2006, Botelho (2012) observou o trânsito entre os docentes das duas áreas de concentração que orientavam teses de doutorado, tanto na Sociologia quanto na Ciência Política, e interpretou o fenômeno como parte da história institucional do IUPERJ, mas também como indício de diálogos cognitivos significativos entre as duas áreas. E como instituições de pesquisa e ensino e revistas acadêmicas fazem parte de um mesmo universo, as características institucionais e intelectuais do IUPERJ/IESP sem dúvida ajudam a entender a clara tendência, percebida na coleção de Sociologia de DADOS, a tratar relações sociais como relações de poder. Ainda que nem essas características institucionais tenham sido estáveis, nem tampouco a tendência cognitiva identificada tenha se apresentado de modo uniforme ao logo dos últimos cinquenta anos nas páginas da revista. Naturalmente, mesmo quando em seus inícios esteve mais ligada à política institucional do antigo IUPERJ, DADOS já era uma revista da comunidade acadêmica das Ciências Sociais brasileiras, inclusive porque instituições de ensino e pesquisa e publicações integram um mesmo universo de significados, respeitadas, porém, suas especificidades e lógicas próprias.

O segundo fator que nos ajuda a entender essa tendência diz respeito a movimentos cognitivos mais amplos (do que a história do IUPERJ/ IESP-UERJ), percebidos no interior da própria Sociologia como disciplina. Analisando vasto material de associações científicas estrangeiras e internacionais, Botelho (2014) observou, no que diz respeito ao relacionamento da sociologia política com a sociologia em geral, como desenvolvimentos da teoria social a partir da chamada "virada cultural", desde os trabalhos pioneiros de Michel Foucault, por exemplo, operaram significativos deslocamentos em relação ao que se costumava pensar como distintivo da sociologia política, mas que hoje aparece generalizado pela Sociologia como um todo. Assim, parece impensável que pesquisas sobre formação de identidades culturais ou mesmo subjetividades privadas, sobre construção de modos de classificação (gênero, raça, classe) e outros possam ser vistos hoje sem serem considerados como instâncias de poder.

Essa ampliação do conceito de poder, passando a abarcar não apenas as instituições políticas formais, mas também os processos políticos in- 
formais, inclusive nas esferas privada e de mercado, certamente não está isenta de consequências teóricas, além de implicar relativa perda de especificidade conceitual. Mas o fato básico sobre o qual se quer argumentar aqui, novamente, é que aquilo que, num primeiro olhar, poderia parecer significar apenas perda de importância da sociologia política, talvez possa significar, antes, que ela tenha acabado por afetar, em seus desenvolvimentos próprios, outras diferentes especialidades e conseguido generalizar, em parte, seus pressupostos, convenções e procedimentos no conjunto da Sociologia como disciplina. Seu aparente declínio, assim, longe de implicar o desaparecimento de sua influência, pode significar também algum êxito em penetrar e, no limite, reorientar cognitivamente diferentes especialidades da Sociologia.

E a tendência a perceber, a construir teoricamente e a tratar todas e quaisquer relações sociais em termos de relações de poder ajuda a entender aquele movimento, em verdade, idiossincrático da sociologia política, ainda que corroborado também por desenvolvimentos paralelos fora da Sociologia, de que, talvez, a microfísica do poder de Foucault seja dos mais relevantes (Foucault, 1975, 1979). Isso para não falar que esse movimento, ainda carente de explicação teórica mais heurística, levou a revisões dos próprios clássicos da Sociologia, de tal modo que, por exemplo, Durkheim pôde ter a "sua" sociologia política redescoberta ou reinventada, não por acaso, por alguns dos principais artífices da sociologia política e da teoria sociológica no século XX, como Steven Lukes, que parece ter desenvolvido paralelamente seus livros Emile Durkheim: His Life and Work. A Historical and Critical Study (1972) e Power: A Radical View (1974); ou Anthony Giddens (1971, 1995), que procurou reabilitar a sociologia política de Durkheim tanto em Capitalism and Modern Social Theory (1971), de modo a poder fazê-lo figurar ao lado de Karl Marx e Max Weber como parte da tríade fundadora da disciplina, quanto em Politics, Sociology and Social Theory (1995) entre outras obras.

Resumindo: tendo em vista tanto estas questões cognitivas mais amplas (a generalização de certos princípios da sociologia política pelo conjunto da disciplina), quanto as configurações particulares anteriormente mencionadas (os condicionantes institucionais e intelectuais do antigo IUPERJ/atual IESP-UERJ), optamos, no presente estudo, por operar com duas dimensões da sociologia política para efeitos de classificação dos artigos: sociologia política como uma "subárea" da sociologia em geral e como um "campo" ou "tradição de pesquisa". Nesse 
contexto, a conhecida distinção proposta por Giovanni Sartori (1969) entre "sociologia da política" ("uma subdivisão do campo geral da sociologia") e "sociologia política" talvez pudesse se mostrar mais produtiva. Todavia, como mesmo quando se buscam complementaridades, e não apenas diferenças entre as disciplinas, a preocupação com o que constituiria uma abordagem sobre a política especificamente sociológica continua presente (Botelho, 2014), preferimos, mais uma vez, perguntar pelos desafios de pesquisa específicos que a sociologia política tem se colocado, isto é, por sua "tradição de pesquisa" (Reis, 1999).

Como ficará mais claro adiante, adotamos, portanto, as seguintes denominações: "Sociologia política como campo", que abrange os artigos classificados como de "sociologia política tout court", como especialidade ou subárea, e os artigos que estabelecem diálogos tanto com outras áreas - Ciência Política, sobretudo - quanto com outras especialidades/subáreas da Sociologia - como a do trabalho, da educação, econômica entre outras, que chamamos de "subgrupos da sociologia política". Importante observar desde já que, se agregadas essas interfaces com outras especialidades, a sociologia política enquanto "campo" apresenta a maior concentração dos artigos da área de sociologia, e que quando as desagregamos, a sociologia política tout court permanece entre as três primeiras colocações.

Apresentaremos adiante os dados nesses dois cenários de modo a mitigar a impressão de que, assim concebida, como um "campo" e não apenas como uma "especialidade" dentre outras, a sociologia política poderá aparecer supervalorizada, em termos quantitativos, em nossa pesquisa. Foi essa a solução que encontramos para enfrentar o problema básico de que, como estamos argumentando, e pelas razões que já aventamos, a sociologia política na revista DADOS compreende ao menos dois desenvolvimentos, não inteiramente livres de ambiguidades. Um em que se expressa a sua diferenciação da Sociologia e da Ciência Política como subdisciplina ou especialidade da primeira em "si mesma" (o que estamos chamando de sociologia política tout court); outro que indica também como a sociologia política vem afetando outras subáreas ou especialidades da Sociologia em geral, criando entre elas interfaces muito significativas. Assim, a distinção proposta visa, antes, controlar a generalização de uma subárea em particular que enviesasse a inteligibilidade do conjunto, do que subscrevê-la, como poderia parecer à primeira vista. Em suma, trata-se de circunscrever um duplo movimento no qual, ao mesmo tempo em que a sociologia políti- 
ca vai se diferenciando em relação às demais especialidades da disciplina e, assim, se consolidando como "subárea", também vai criando ramificações e se modificando, a partir de sua agenda própria de pesquisas, abordagens e temáticas de outras subáreas e da própria disciplina em geral, processo também visível na incorporação pelo "campo" de questões tradicionalmente pertencentes ao escopo de outras agendas de pesquisa e especialidades.

A classificação proposta visa sobretudo dar inteligibilidade, então, ao caráter dinâmico assumido pelo movimento de diferenciação que, ao longo dos cinquenta anos de publicação da revista DADOS, vai criando novas conexões e interfaces significativas entre diferentes subáreas ou especialidades da Sociologia. Assim, dada sua relevância quantitativa e qualitativa, a sociologia política pode constituir ainda um eixo heurístico para a compreensão das continuidades e mudanças da Sociologia nas páginas da revista DADOS e a partir delas. Como veremos adiante, com a distinção proposta, a sociologia política nos ajudará a perceber mudanças ocorridas não apenas na maneira de fazer sociologia política, mas também na própria concepção do que se tornou, então, nesses cinquenta anos, fazer teoria sociológica. Não teríamos essa dimensão do todo se tomássemos como eixo, por exemplo, a subárea da estratificação social, cuja produção se mantém muito constante em termos quantitativos e qualitativos; ou mesmo a teoria sociológica, cuja produção não é tão expressiva quanto veio a se tornar depois dos anos 1990; ou a sociologia do trabalho, que parece incialmente estar muito ligada a problemas da sociologia política; e a subárea do pensamento social, que também parece estar inicialmente muito ligada aos problemas da sociologia política para, depois, passar a se associar mais aos problemas da teoria sociológica lato sensu.

Cabe fazer uma última ponderação: estamos lidando com artigos que, naturalmente, possuem autoria definida e publicamente conhecida. No caso analisado, há clara presença de autoria de sociólogos que são ou foram pesquisadores do staff do antigo IUPERJ e do atual IESP-UERJ. Seria artificial ignorar que, por isso mesmo, muitos dos movimentos mais interessantes observados na sua coleção de sociologia ao longo das últimas cinco décadas estejam também ligados às trajetórias acadêmicas e intelectuais, coletivas e individuais desses autores/pesquisadores, inclusive dentro das instituições mantenedoras da revista. Deve-se destacar, no entanto, que o grau de vinculação entre pesquisadores, instituições e seus meios de publicação acadêmica está 
relacionado à diferenciação institucional das Ciências Sociais brasileiras, e não é à toa que aquela vinculação seja mais forte, sobretudo, nas três primeiras décadas de publicação da DADOS (cf. neste número Campos, Feres Jr. e Guarnieri, 2016). A criação de programas de pósgraduação em Ciências Sociais, com significativa expansão nos anos 1970 e ainda maior a partir dos anos 2000 (Maia et al., 2016), diversificou a comunidade acadêmica e certamente influiu nas dinâmicas de publicação. Tendo isso em vista, ao invés de enfatizar ou sobrevalorizar a criação de vieses nos dados coletados em decorrência daquelas trajetórias, ou de ignorá-los artificialmente, preferimos reconhecê-los, como o leitor familiarizado com o universo empírico da nossa pesquisa fatalmente também o fará.

Entendemos, no entanto, que o caso pesquisado não é idiossincrático aos padrões de publicação das Ciências Sociais no Brasil, e também noutras instituições estrangeiras; e, mais importante ainda, que ele, na verdade, repõe em termos próprios o problema sociológico básico da relação indivíduo e sociedade. Se toda identidade é relacional, onde mais buscar a identidade de DADOS senão na relação entre os enviesamentos individuais, ligados aos autores/atores, e institucionais, associados à política editorial da revista? É, pois, na relação entre "movimentos" e "enviesamentos", isto é, entre "processos" e "agentes" que se modelou a revista DADOS e que se torna inteligível um capítulo fundamental da história do IUPERJ/IESP-UERJ e também das Ciências Sociais brasileiras.

\section{A COLEÇÃO SOCIOLOGIA DA REVISTA DADOS}

Tendo em vista os parâmetros mais gerais de nossa classificação apresentados anteriormente, expomos a seguir alguns dados sistematizados na pesquisa. O Quadro 1 apresenta todos os 369 artigos publicados na revista DADOS, do número 1, no segundo semestre de 1966, até o volume 59 (número 1) de 2016, identificados como "Sociologia"3.

Como se pode perceber, os dados justificam a nossa escolha por tomar a sociologia política como foco da análise: primeiro porque sua produção é preponderante até os anos 1980; segundo porque o "campo" da sociologia política foi o responsável pela maioria dos artigos em Sociologia publicados na revista, respondendo por 93 (25\%) dos 369 artigos nesses cinquenta anos, 46 artigos a mais que "pensamento social e político brasileiro" e 48 a mais que "teoria sociológica", respectivamente, a 


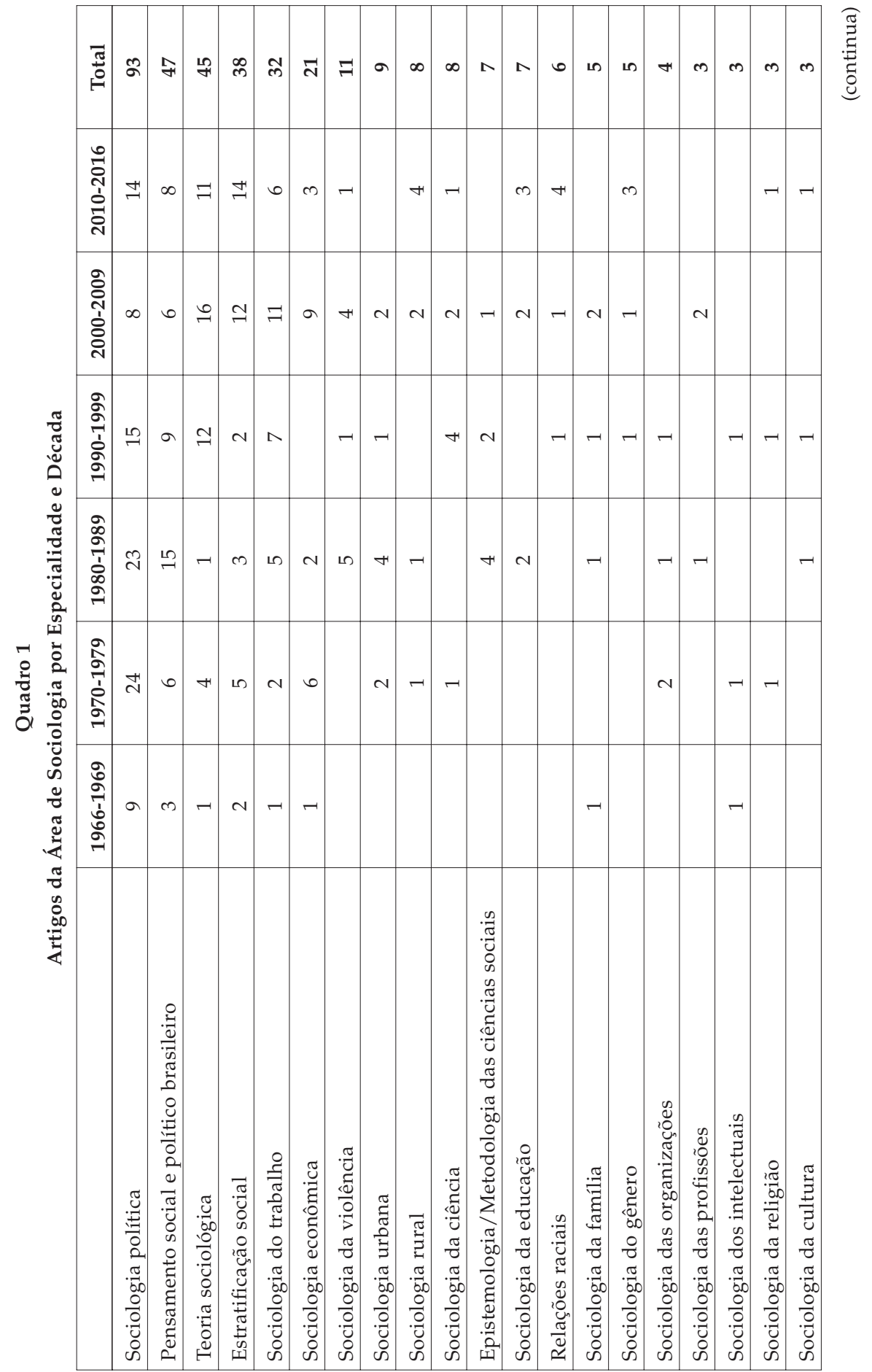

714 DADOS - Revista de Ciências Sociais, Rio de Janeiro, vol. 60, nº 3, 2017 


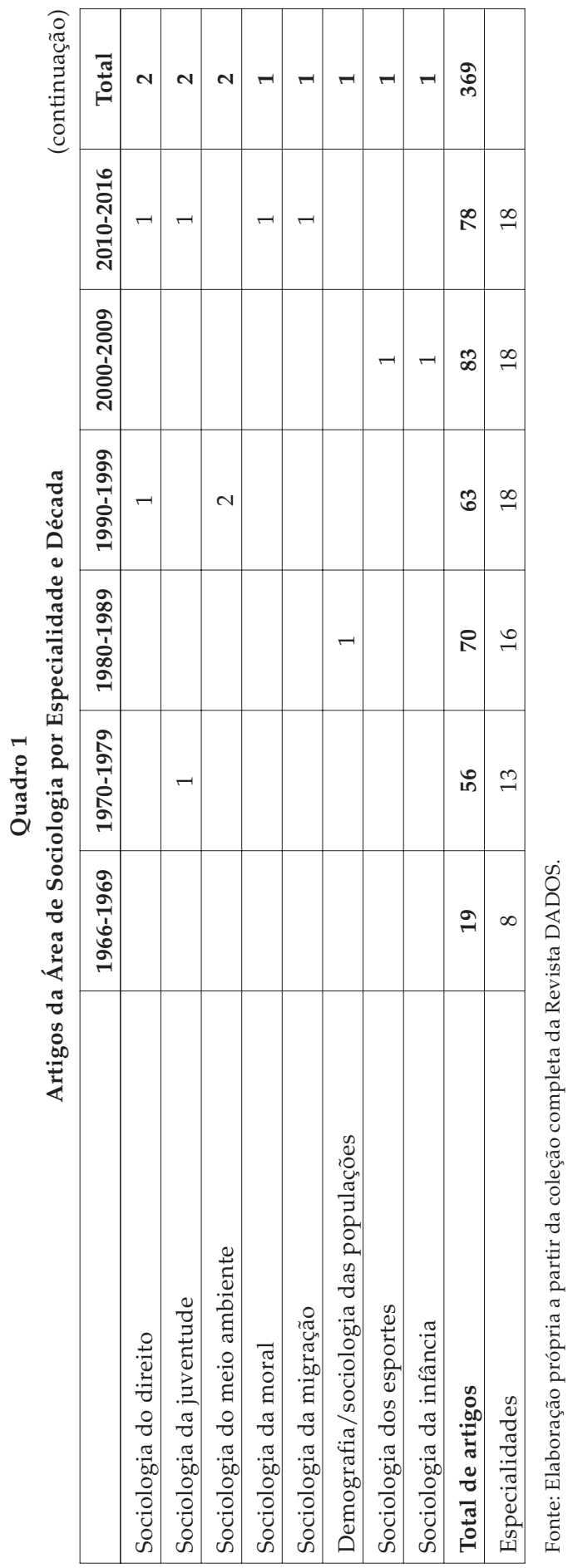

DADOS - Revista de Ciências Sociais, Rio de Janeiro, vol. 60, nº 3, 2017715 
segunda e terceira especialidades mais recorrentes. Prosseguiremos no detalhamento da sociologia política na próxima seção; antes disso, porém, vejamos ainda alguns dados e indicadores mais gerais.

A distribuição por gênero dos autores e coautores dos artigos publicados nas dez áreas mais recorrentes na coleção Sociologia da revista DADOS é predominantemente masculina. Como a base de levantamento foi a autoria dos artigos, um(a) mesmo(a) autor(a) pode ter sido contabilizado(a) mais de uma vez. Vemos, assim, que, no universo total de artigos da área de Sociologia, contabilizamos o total de 447 autorias, sendo 296 masculinas (67\%) e apenas 151 femininas (33\%). No Quadro 2, vemos que a divisão por gênero das dez primeiras subáreas da Sociologia em relação ao total de autores e coautores guarda correspondência exata: $67 \%$ (252) de autoria ou coautoria masculina e 33\% (126) feminina.

Quadro 2

Gênero segundo a Autoria de Artigos

\begin{tabular}{|l|c|c|}
\hline & Feminino & Masculino \\
\hline Sociologia política & 41 & 70 \\
\hline Pensamento social e político brasileiro & 17 & 36 \\
\hline Teoria social/sociológica & 6 & 42 \\
\hline Estratificação social & 15 & 34 \\
\hline Sociologia do trabalho & 13 & 26 \\
\hline Sociologia econômica & 8 & 20 \\
\hline Sociologia da violência & 11 & 2 \\
\hline Sociologia urbana & 2 & 7 \\
\hline Sociologia rural & 8 & 6 \\
\hline Sociologia da ciência & 5 & 9 \\
\hline
\end{tabular}

Fonte: Elaboração própria a partir da coleção completa da Revista DADOS.

A seguir, o Quadro 3 apresenta as dez filiações institucionais mais recorrentes dos autores no momento da publicação. A contabilização foi feita baseando-se na filiação institucional - ou mais de uma, quando declarada - dos autores de cada artigo de nosso levantamento geral para a área de Sociologia (o que, não raro, fez com que o mesmo autor entrasse mais de uma vez, embora não necessariamente na mesma instituição). Nota-se o número expressivo de autores pertencentes ao próprio IUPERJ / IESP-UERJ (133 ou 28\% do total das autorias) e a instituições estrangeiras (86 ou 18\% do total das autorias). As instituições da 
região Sudeste (excetuando-se IUPERJ/IESP-UERJ) respondem por 205 ou 42,88\% do total das autorias, a região Sul e a região Nordeste estão muito próximas no número de autorias, respectivamente 19 ou $3,97 \%$ e 17 ou 3,55\%, enquanto a Centro-Oeste (representada pela Universidade de Brasília - UnB) tem 6 autorias (1,25\%) e não há autores filiados a instituições da região Norte. As demais instituições, classificadas como nacionais (Instituto de Pesquisa Econômica Aplicada IPEA; Financiadora de Estudos e Projetos - FINEP; e Instituto Rio Branco, por exemplo) têm 14 ou 2,92\% das autorias.

Deixando a apresentação dos dados relativos à sociologia política para a próxima seção, vejamos aqueles relativos às outras quatro subáreas/especialidades com maior número de publicações em DADOS (com dois ou mais artigos). Como vimos, "pensamento social e político brasileiro" encontra-se em segundo lugar, após a sociologia política como "campo", com 47 artigos ou 13\% do total de artigos da revista. Talvez por ser uma subárea marcada pela interdisciplinaridade e cuja tendência tem sido justamente a de conjugar diversas perspectivas analíticas (Bastos e Botelho, 2010), ela tem se mantido relativamente estável ao longo dos anos, excetuando-se os anos 1980 com significativa produção, com 21\%, e os anos 2000, com apenas 7\%. Como se observa no Quadro 4, a produção nesta subárea foi alavancada, sobretudo, por José Murilo de Carvalho (6 artigos), Lúcia Lippi e Luiz A. de Castro Santos (3 artigos cada).

Com o total de 45 artigos (12\% das publicações), a subárea "teoria social/sociológica" teve um forte incremento a partir dos anos 1990 e 2000, com 12 e 16 artigos publicados respectivamente, representando $19 \%$ do total em cada um desses decênios. José Maurício Domingues é autor de 10 artigos ao todo, destes, 3 nos anos 1990 e 5 nos anos 2000 (Quadro 5).

A terceira subárea com maior produção foi a de "estratificação social", com 38 artigos ou 10\% das publicações totais, apresentando a partir dos anos 2000 substancial aumento em sua publicação, com 12 artigos ( $14 \%$ em relação ao total) e com forte tendência de crescimento no decênio ainda inacabado de 2010 (14 artigos e aumento de 4\%). Carlos Antônio Costa Ribeiro (6 artigos), Nelson do Valle Silva, José Alcides Figueiredo dos Santos (5 artigos cada um) e Carlos Hasenbalg e Maria Celi Scalon (3 artigos cada) são os autores mais publicados nessa subárea (Quadro 6). 


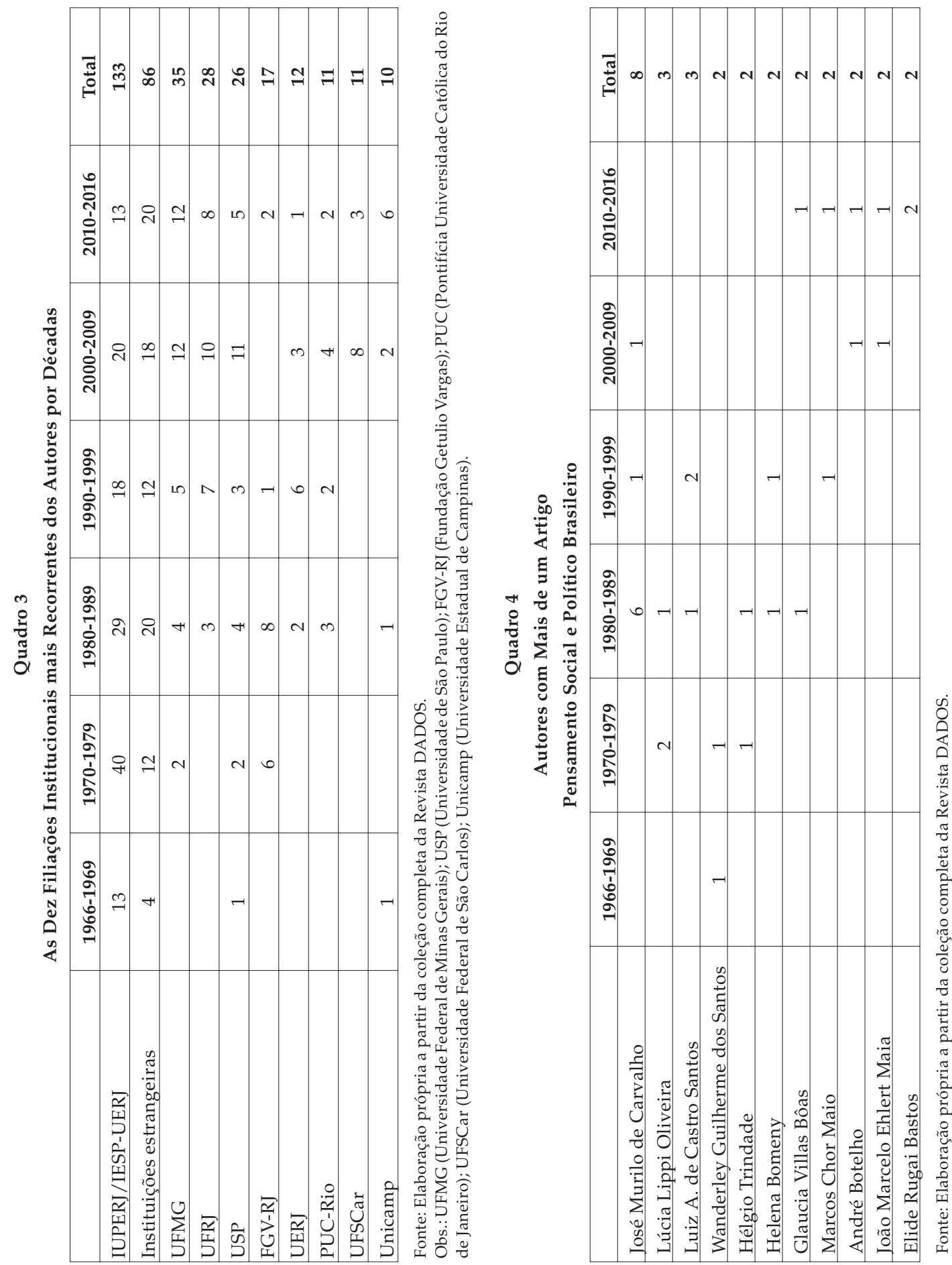

718 DADOS - Revista de Ciências Sociais, Rio de Janeiro, vol. 60, nº 3, 2017 
A Sociologia e a Sociologia Política em DADOS
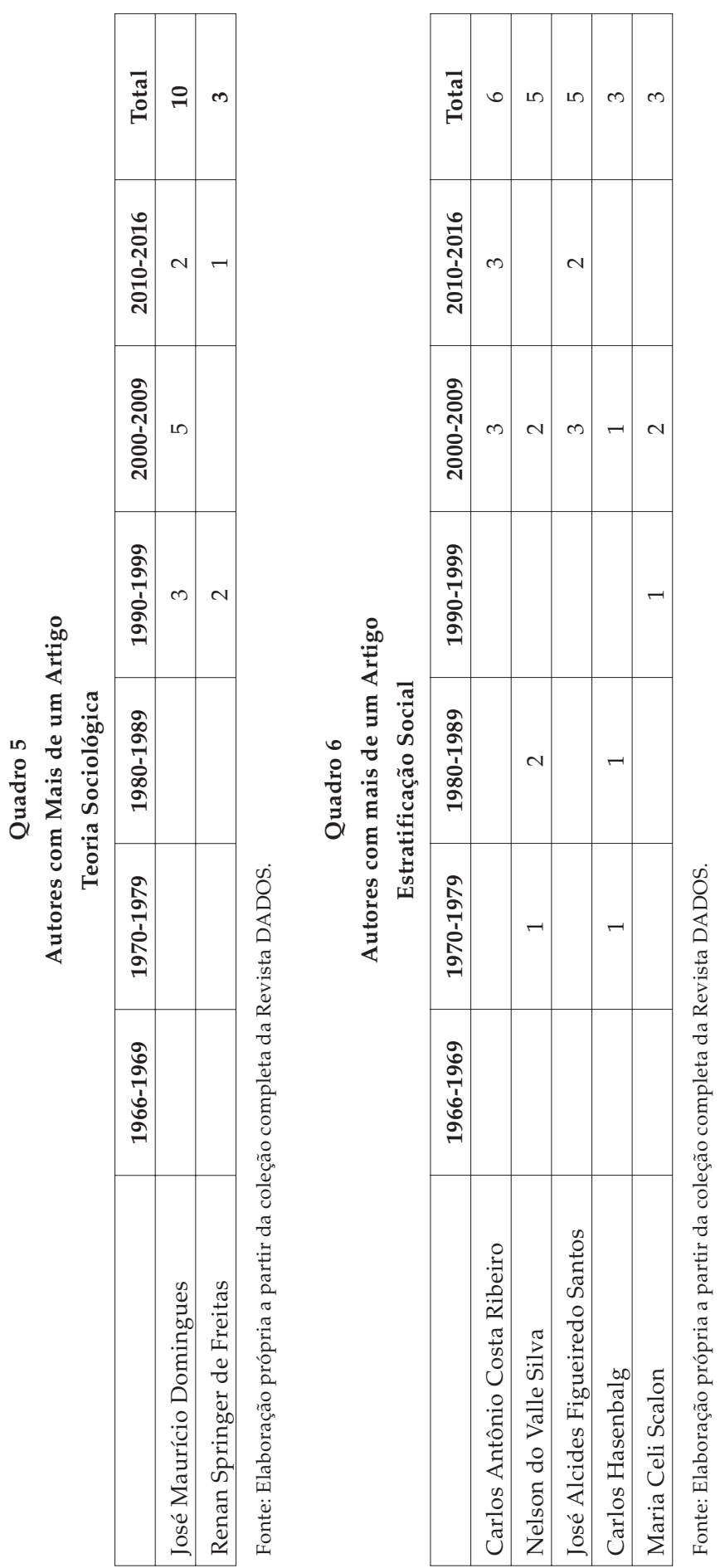

DADOS - Revista de Ciências Sociais, Rio de Janeiro, vol. 60, nº 3, 2017719 
A subárea "sociologia do trabalho" fecha a lista com 33 publicações (9\% do total), com expressivo aumento a partir dos anos 1990 e 2000, quando passa a responder por $11 \%$ e $13 \%$ em cada período respectivamente, e, ao contrário das demais subáreas citadas, apresenta uma tendência de queda no decênio de 2010. Como se observa no Quadro 7, os autores com mais de uma publicação são Adalberto Cardoso (6 artigos), Nadya Araújo Guimarães (3 artigos), Elizabeth Jelin e José Ricardo Ramalho (2 artigos cada).

\section{SOCIOLOGIA POLÍTICA: ACOPLAMENTOS E DESACOPLAMENTOS}

Até os anos 1980 foi expressiva a publicação da sociologia política como "campo" no escopo da revista DADOS. Embora nos anos 1960 tenham sido editados somente seis números, os artigos em sociologia política foram responsáveis por $47 \%$ da publicação na área de Sociologia, enquanto a subárea "pensamento social e político brasileiro" por $16 \%$ e "estratificação social e desigualdades sociais" por 11\% (conforme Quadro 1). Esses números se alteram nos anos 1970 e 1980, passando a sociologia política a responder por $43 \%$ e $33 \%$ das publicações, respectivamente. A partir dos anos 1990 tornou-se perceptível uma forte queda da produção da subárea de sociologia política (9\% em relação aos anos 1980), concomitantemente a um aumento da publicação de artigos nas mais diversas áreas que vinha ocorrendo desde os anos 1970. A passagem dos anos 1980 para os 1990 foi assim reveladora de um processo de maior especialização em curso, já que as publicações de DADOS se diluem em 18 especialidades classificadas, contabilizando $24 \%$ em sociologia política e $76 \%$ nas demais especialidades, ou seja, uma queda de $23 \%$ em relação aos anos 1960 . É preciso atentar, portanto, que ao longo dos anos houve não só um aumento do número no conjunto de publicações em diversas especialidades fora do "campo" da sociologia política (de 53\% nos anos 1960 para 90\% nos 2000, conforme o Quadro 8), como também uma maior variedade dessas especialidades (eram 8 nos anos 1960, passando a 13 nos anos 1970 e 16 nos anos 1980, e se estabilizando em 18 a partir dos anos 1990, conforme o Quadro 1).

Vejamos a seguir os autores que publicaram mais de um artigo identificado como sociologia política (Quadro 9).

Um dado complementar e significativo da relação que estamos identificando entre a sociologia política e o universo de DADOS é o forte 
A Sociologia e a Sociologia Política em DADOS

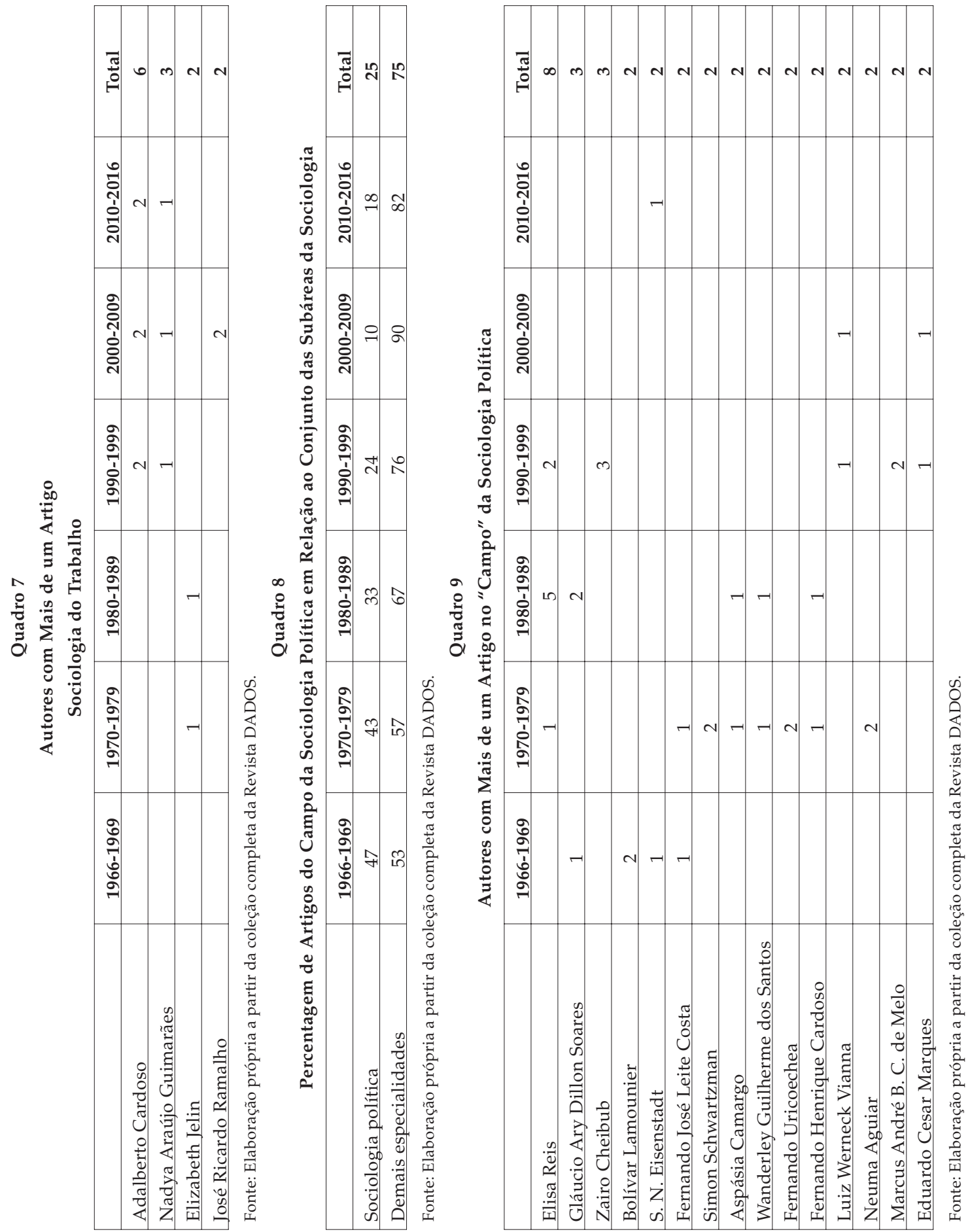

DADOS - Revista de Ciências Sociais, Rio de Janeiro, vol. 60, nº 3, $2017 \mathbf{7 2 1}$ 


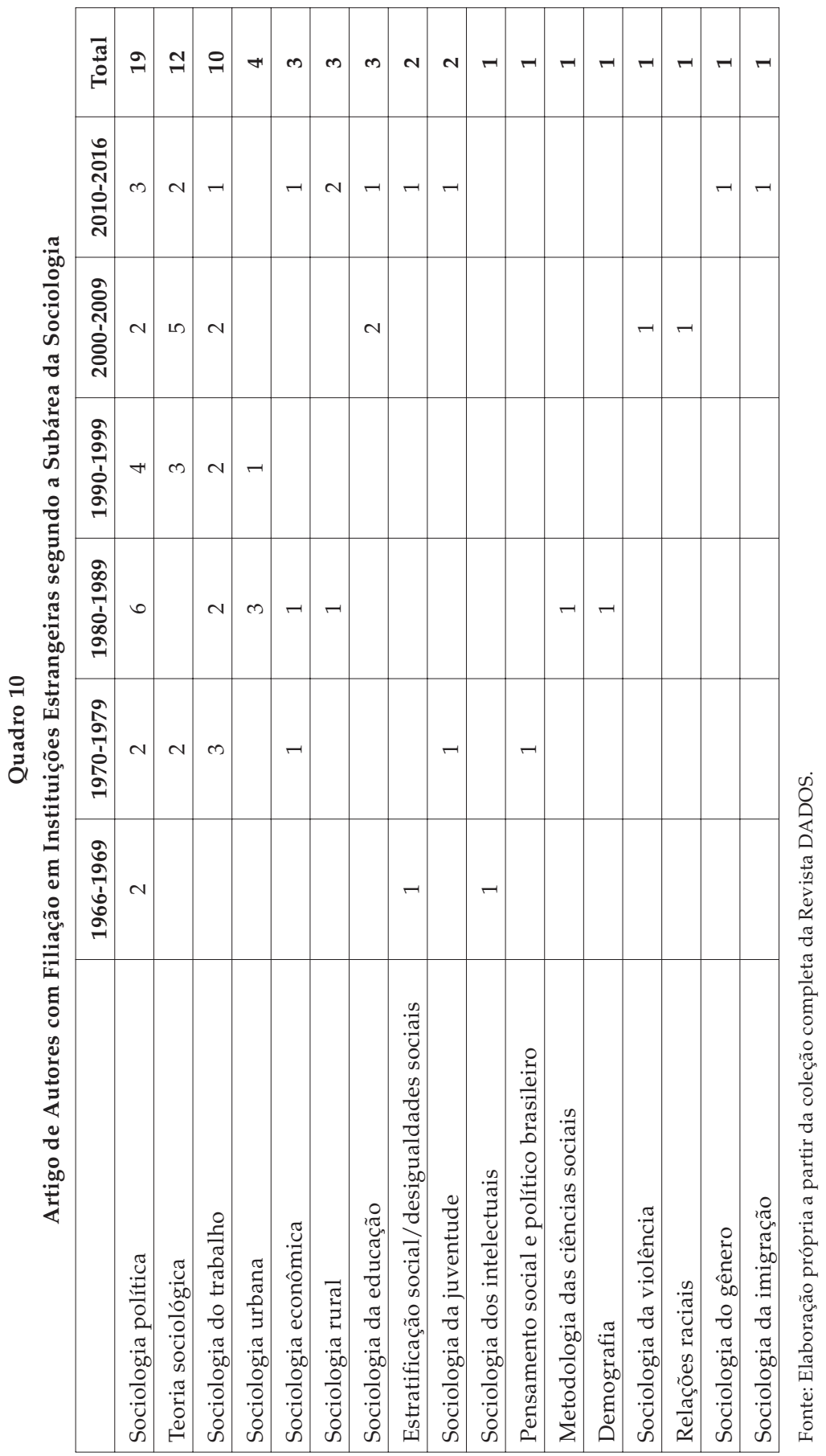

722 DADOS - Revista de Ciências Sociais, Rio de Janeiro, vol. 60, nº 3, 2017 
investimento da revista, nesse "campo", na publicação de artigos de autores com filiação institucional no exterior. No Quadro 10 vemos o número de artigos de autores com filiação institucional estrangeira o que não significa que sejam estrangeiros -, e é notória a importância da "sociologia política" com 19 (29\%) dos 66 artigos do total. "Teoria sociológica" aparece em segundo com 12 artigos (18\% do total), seguida por "sociologia do trabalho" com 10 artigos (15\%). As subáreas de sociologia política e sociologia do trabalho são as mais regulares em publicações ao longo do ano, muito embora o número superior de publicação da primeira. A partir dos anos 1990 a subárea "teoria sociológica" passa a ter o maior número de publicações (10) em relação à "sociologia política" (9) e "sociologia do trabalho" (5). Além disso, os dados parecem corroborar a tendência que estamos investigando até agora, qual seja, a de que os anos 1980 são um momento de transição para o "campo" da sociologia política. Há uma crescente especialização, com exceção dos anos 1990, dos temas da área de Sociologia revelada pela quantidade de artigos em outras subáreas.

Esse amplo quadro da produção em Sociologia da revista DADOS é importante para entendermos as mudanças ocorridas no interior daquilo que chamamos aqui como o "campo" da sociologia política, ou seja, espaço de intersecção e de interlocução de artigos que se situam no limiar entre diferentes especialidades da Sociologia, mas que, devido à ênfase em temas centrais como a relação Estado e sociedade e as diversas formas de organização do poder que compõem determinadas relações sociais, foram classificadas em nosso levantamento geral como pertencendo à sociologia política (conforme Quadro 1). Dada a força centrípeta desses aspectos teórico-metodológicos durante certo período, o "campo" abrange os artigos classificados como de sociologia política tout court, como especialidade ou subárea, e os artigos que estabelecem diálogos tanto com outras áreas - Ciência Política, sobretudo -, quanto com outras especialidades/subáreas da Sociologia como trabalho, econômica, educação, entre outras.

São muitas as especialidades ou subdisciplinas da Sociologia que podemos surpreender nas páginas de DADOS, refazendo, a seu modo, aquele movimento mais geral de ampliação do conceito de poder que, como estamos argumentando, também vai criando novas intersecções significativas entre a sociologia política e demais especialidades da Sociologia ou de outras disciplinas, como a Ciência Política. Uma das mais significativas é a intersecção entre sociologia política e sociologia 
do trabalho, na qual se destacam o interesse crescente pelo comportamento político da "classe operária" urbana e suas formas de ação coletiva (n-1, 1966; no 11, 1973; no 15, 1977; vol. 23, 1980; vol. 24, 1981; vol. 26, 1983; vol. 53, 2010; vol. 55, 2012). Como exemplo, observamos que Leôncio Martins Rodrigues comparece já no primeiro número da revista com o artigo "Considerações sobre o Comportamento Operário"; o tema volta às páginas da revista com Eunice Durham, em "A Família Operária: Consciência e Ideologia", publicado no volume 23, de 1980.

Até aqui apresentamos os dados sobre o "campo" da sociologia política e o acoplamento em seu interior de subáreas da Sociologia ou mesmo de outras áreas, notadamente a Ciência Política. Vejamos agora o cenário de publicações da área de Sociologia da revista DADOS a partir do desmembramento do "campo" da sociologia política, redistribuindo pelas subáreas da Sociologia os artigos que em seu interior não foram classificadas como sociologia política tout court, ou seja, aqueles que não tomaram as relações entre Estado e sociedade como dimensão central da investigação e até mesmo da teoria sociológica.

Considerando a relação entre o "campo" da sociologia política e as demais subáreas, é possível perceber que, na década de 2000, esse movimento de especialização disciplinar atinge seu máximo com $90 \%$ das publicações (conforme o Quadro 8). Internamente ao "campo" da sociologia política, há um movimento análogo e concomitante de especialização disciplinar, decrescendo o número da produção em sociologia tout court e crescendo a produção da sociologia política em diálogo com as subáreas da Sociologia, como demonstra o Quadro 11.

Quadro 11

Produção Interna ao "Campo" da Sociologia Política

\begin{tabular}{|l|c|c|c|c|c|c|}
\hline & $\mathbf{1 9 6 6 - 1 9 6 9}$ & $\mathbf{1 9 7 0 - 1 9 7 9}$ & $\mathbf{1 9 8 0 - 1 9 8 9}$ & $\mathbf{1 9 9 0 - 1 9 9 9}$ & $\mathbf{2 0 0 0 - 2 0 0 9}$ & $\mathbf{2 0 1 0 - 2 0 1 6}$ \\
\hline Sociologia tout court & $67 \%$ & $46 \%$ & $39 \%$ & $40 \%$ & $38 \%$ & $43 \%$ \\
\hline Subgrupos da sociologia política & $33 \%$ & $54 \%$ & $61 \%$ & $60 \%$ & $63 \%$ & $57 \%$ \\
\hline
\end{tabular}

Fonte: Elaboração própria a partir da coleção completa da Revista DADOS.

Uma das explicações reside em processos que vinham das décadas anteriores ejá se tornam perceptíveis nos anos 1980, quando as mudanças institucionais das Ciências Sociais no Brasil se fazem sentir de forma significativa, em razão das políticas dos governos militares direcionadas à ciência e tecnologia, cuja expressão maior foi a reforma universitária (1968), a expansão de vagas no ensino superior, além da atuação 
de instituições internacionais - como a Fundação Ford - na criação de programas de pós-graduação, da qual o próprio IUPERJ fez parte. As mudanças institucionais de produção de conhecimento em Ciências Sociais no Brasil, aliando ensino e pesquisa, reforçadas ainda pela circulação e formação de pesquisadores em grandes centros do mundo, dotaram a produção científica da especialização requerida pelos padrões internacionais. Não à toa, a partir das décadas de 1970 e 1980, se apresenta um movimento de crescente especialização da área de Sociologia, tendência que se mantém até os nossos dias.

Os anos 1980 parecem mais significativos se levarmos em conta, mais uma vez, os movimentos interno e externo ao "campo" da sociologia política. Como já dito, a década de 1980 solidifica uma tendência que é anterior a ela e prossegue depois dela, que é a da especialização da área de Sociologia. Ao mesmo tempo, internamente ao "campo" da sociologia política há uma produção crescente de artigos que, embora integrados nesse "campo", estabelecem um forte diálogo com outras especialidades. Se na década de 1970, conforme o Quadro 12 a seguir, o subgrupo mais forte no interior do "campo" da sociologia política foi formado por artigos que se articulavam com a área de Ciência Política (com 46\% da produção), na década de 1980 houve uma verdadeira pulverização das especialidades, com "políticas públicas" respondendo por $14 \%$ da produção total e "sociologia do trabalho" e "sociologia econômica" cada uma por 21\%. Na década de 1990 essa pulverização já não mais existe internamente ao "campo" da sociologia política, mas se reflete externamente a ele, fazendo com que a publicação de artigos nas mais diversas especialidades atinja o patamar de $76 \%$ do total da área de Sociologia, chegando a 90\% nos anos 2000 (ver Quadro 8). Essa tendência parece ser de escopo mais geral e não particular ao universo empírico da DADOS, já que pesquisas recentes sobre produção das Ciências Sociais brasileiras, referentes sobretudo à ANPOCS, demonstram como grupos de trabalho e seminários de pesquisa agrupados sob o tema de "sociologia e antropologia política" estão entre os cinco mais recorrentes ao longo da história da instituição, embora, em movimento análogo ao destacado aqui, estejam em queda nas últimas décadas (Botelho, Ricupero e Brasil Jr., 2016).

Em relação aos artigos classificados como de sociologia política tout court é possível observar uma queda das publicações ao longo dos anos, apesar da tendência de crescimento verificada no decênio de 2010 em curso (Quadro 11). Um eixo principal de análise se destaca no 


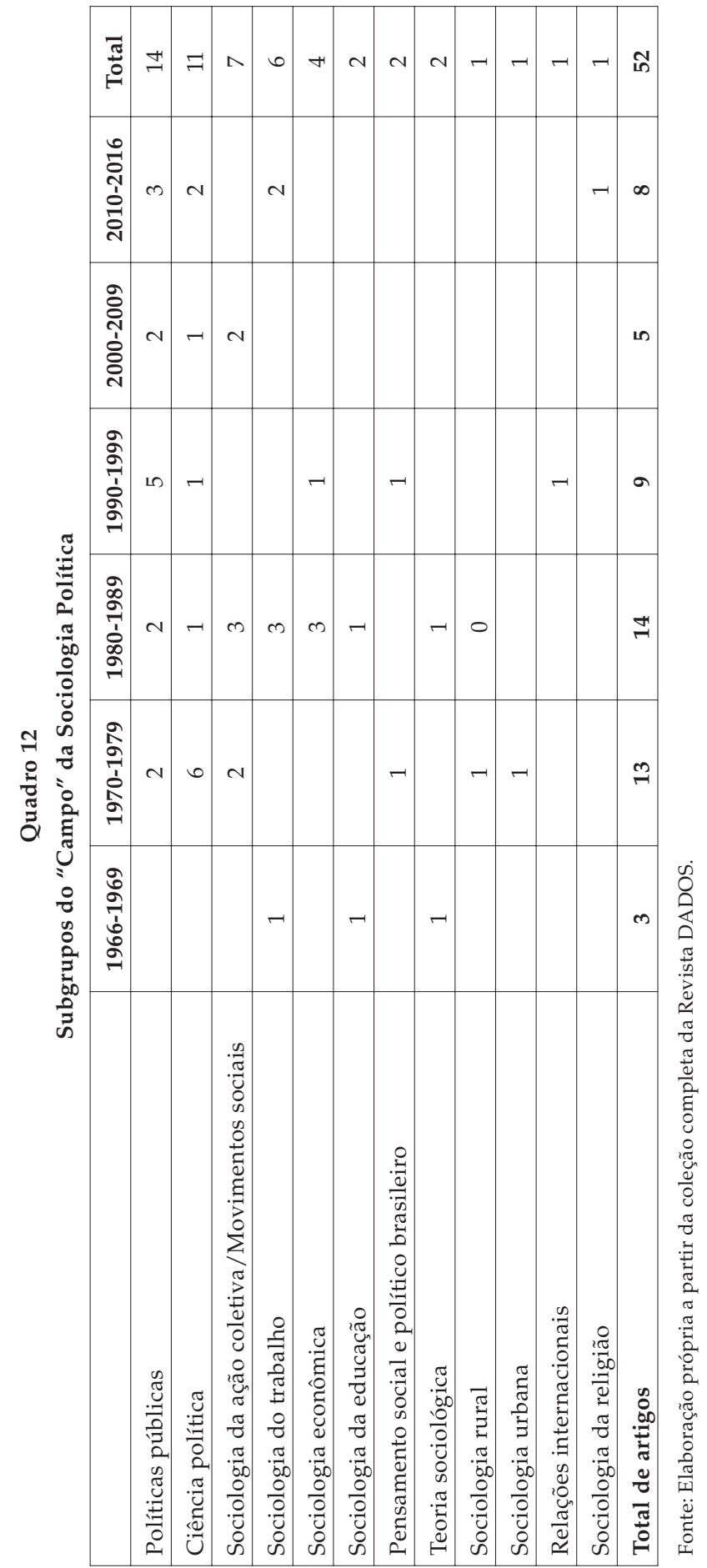

726 DADOS - Revista de Ciências Sociais, Rio de Janeiro, vol. 60, nº 3, 2017 
conjunto de artigos que compõem esse subgrupo do campo da sociologia política: a formação do Estado-nação no Brasil, abarcando variados períodos históricos, bem como, por vezes, análises conjunturais. A partir dessa temática mais ampla, questões correlatas tiveram maior destaque, como a questão agrária e aspectos da sociedade tradicional brasileira, o caráter da autoridade estatal (patrimonialismo, autoritarismo, populismo) e, por fim, formas de organização política das elites e de ação coletiva de trabalhadores e camadas populares.

No Quadro 13 visualizamos a situação da sociologia política tout court em face da produção geral da Sociologia em números absolutos. Neste novo cenário da pesquisa, o "campo" da sociologia política foi desmembrado de maneira que os seus subgrupos passassem a ser contabilizados dentro de outras subáreas da Sociologia, figurando a sociologia política tout court também como uma subárea. Aqueles artigos dos subgrupos do "campo" da sociologia política com interface com a Ciência Política foram retirados do cômputo geral, pois nesse novo cenário eles extrapolaram a área da Sociologia. Portanto, o total de artigos cai para 359, 10 a menos em relação ao total do cenário do "campo" da sociologia política. Além disso, surgiram três novas subáreas / especialidades: "sociologia da ação coletiva/movimentos sociais", "políticas públicas" e "relações internacionais". Nesse novo cenário a sociologia política cai para terceiro lugar com 41 artigos (11\% do total), fato que revela, mesmo quando deflacionamos o "campo", a importância dessa temática no universo empírico de DADOS.

Vejamos agora de modo mais detido os artigos da sociologia política tout court, isto é, nesse novo cenário, a partir do desmembramento do "campo" da sociologia política. Como observamos, aquela compreende artigos que tomaram as relações entre Estado e sociedade e as relações de poder aí envolvidas como dimensão central da investigação e até mesmo da teoria sociológica. São artigos publicados desde o no 2, de 1967, ao vol. 58, no 4, de 2015. Inclui autores que se tornaram verdadeiros clássicos da disciplina e da área de pesquisa que, justamente por isso e pelo que expressam de um programa forte de formação desta disciplina/área de pesquisa, vale assinalar. A começar pela versão de "O Código do Sertão: Um Estudo sobre Violência no Meio Rural” (1968), um dos capítulos de Homens Livres na Ordem Escravocrata, de Maria Sylvia de Carvalho Franco (1969), o artigo é central na tese de doutorado da autora, Homens Livres na Velha Civilização do Café, orientada por Florestan Fernandes, defendida em 1964 perante a comissão exa- 


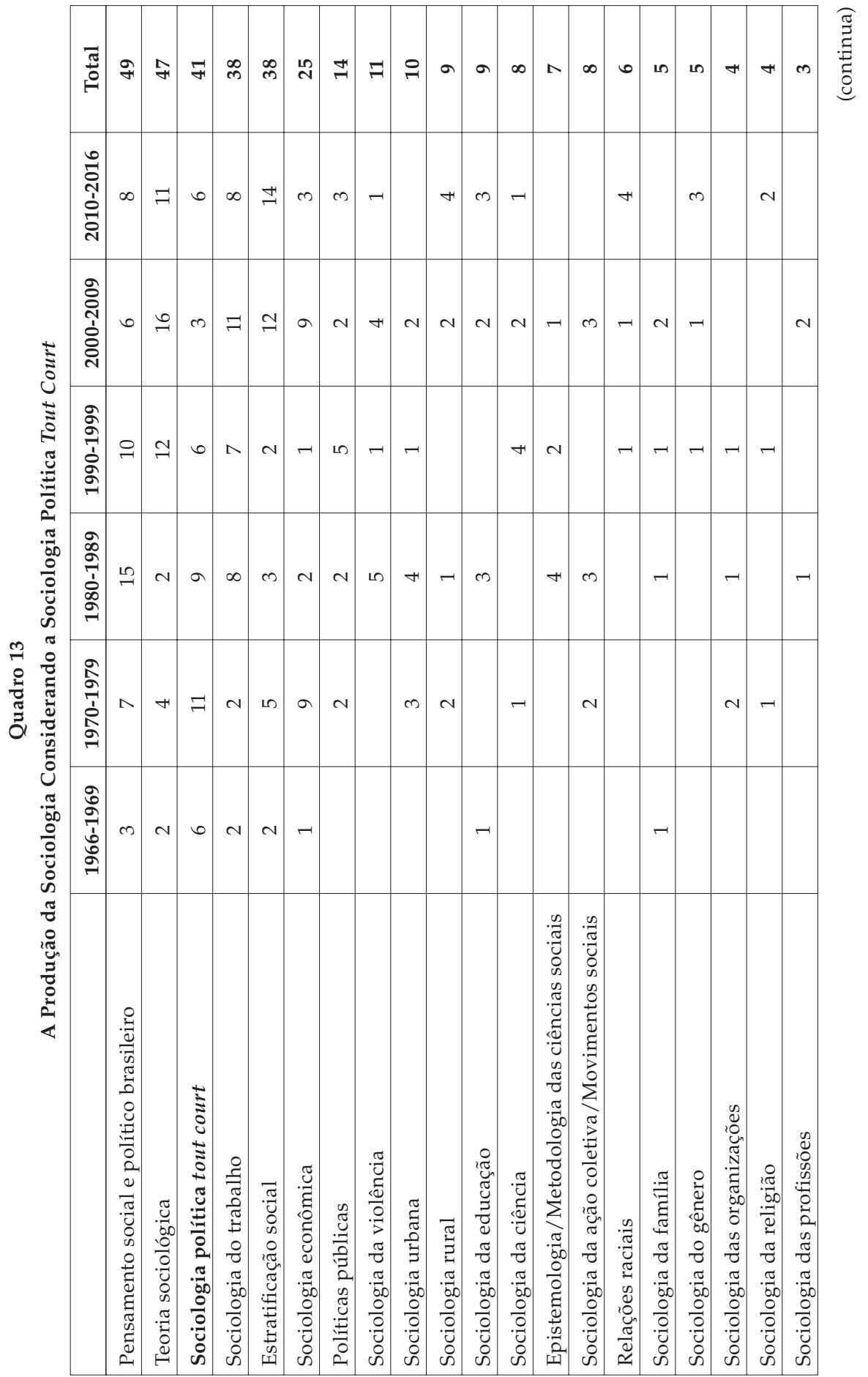

728 DADOS - Revista de Ciências Sociais, Rio de Janeiro, vol. 60, nº 3, 2017 


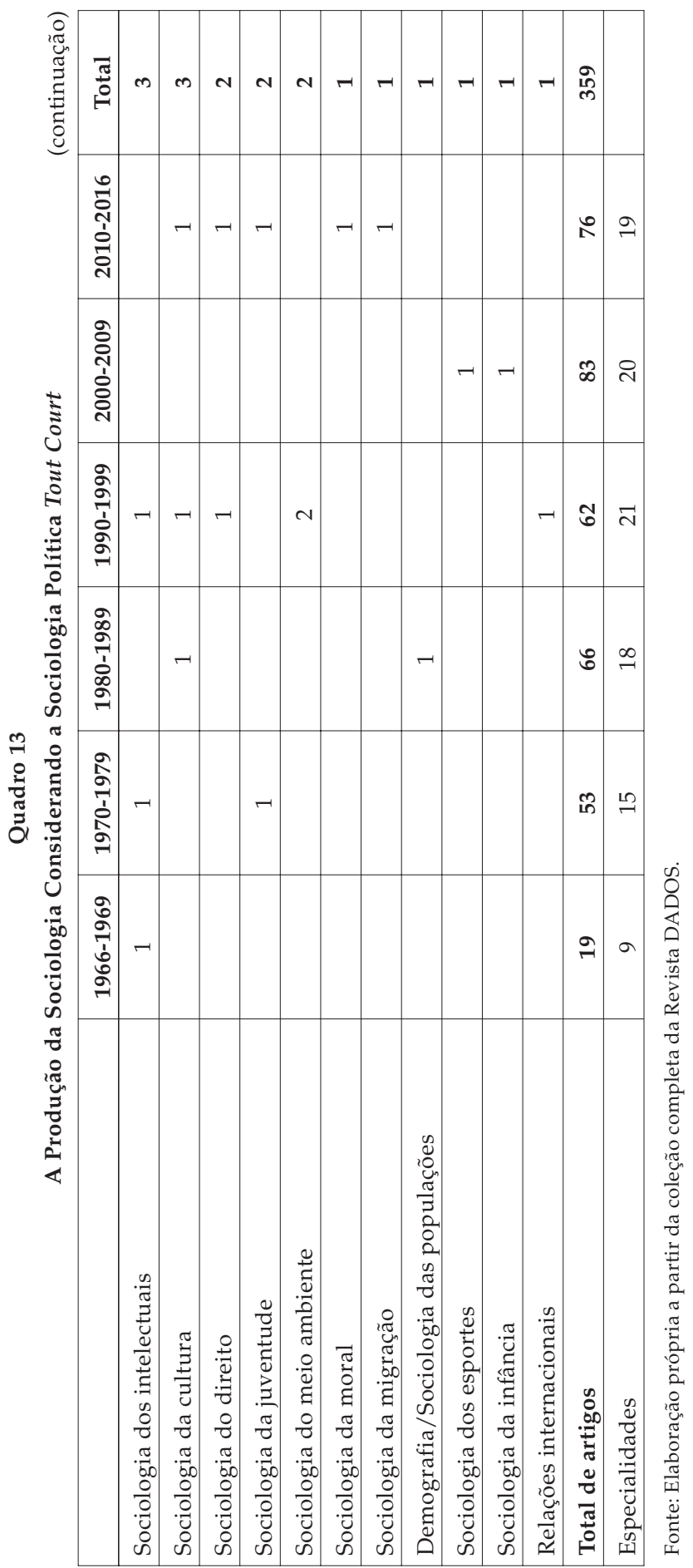

DADOS - Revista de Ciências Sociais, Rio de Janeiro, vol. 60, nº 3, 2017729 
minadora composta por Antonio Candido, Sérgio Buarque de Holanda, Octavio Ianni e Francisco Iglesias, além do orientador. O livro de Maria Sylvia de Carvalho Franco vem sendo estudado como peça central na sociologia política brasileira, com ambições e alcances teóricos notáveis, seja no debate sobre Estado-sociedade e patrimonialismo no Brasil (Vianna, 1999), seja no debate weberiano mais amplo sobre teoria e historia (Botelho, 2013), seja na formação de várias especialidades acadêmicas, como a sociologia da violência brasileira contemporânea (Hoelz, 2010).

Em trabalho publicado justamente em DADOS, Botelho (2007) sugere que a obra de Maria Sylvia de Carvalho Franco constitui o ponto de chegada mais consistente em termos teórico-metodológicos da formação de uma sociologia política no Brasil. Formada entre os anos 1920-1970, essa vertente bastante heterodoxa do ponto de vista doutrinário e político envolve ensaios de Oliveira Vianna e pesquisas acadêmicas realizadas, entre outros, por Victor Nunes Leal, Luiz de Aguiar da Costa Pinto, Maria Isaura Pereira de Queiroz, além da própria Maria Sylvia de Carvalho Franco. Investigando diferentes fenômenos políticos, como clãs rurais, clientelismo, lutas de famílias, voto de cabresto e dominação pessoal, os trabalhos analisados convergem, no plano teórico-metodológico, para uma abordagem que se quer diferencialmente sociológica da política. Entendendo por abordagem "sociológica" a ênfase nas bases sociais do Estado e da vida política, em suas relações com a estrutura social e com as condições de protagonismo dos atores sociais, no lugar de uma lógica institucional autônoma que viria a caracterizar, em grande medida, o desenvolvimento da Ciência Política no Brasil (Lamounier, 1982). Ao articularem aquisição, distribuição, organização e exercício de poder político à estrutura social, aqueles trabalhos recusam a ideia de que as instituições seriam por si mesmas capazes de transformar a dinâmica social e que, portanto, pudessem constituir variáveis autônomas na explicação do Estado e da vida política. A propósito, o próprio Victor Nunes Leal, publica no vol. 23, no 1, de 1980, importante artigo revisitando sua obra clássica, Coronelismo, Enxada e Voto. O Município e o Regime Representativo no Brasil, de 1949, formulado originalmente no ano anterior como tese para provimento da Cadeira de Política da Faculdade Nacional de Filosofia da então Universidade do Brasil, atual Instituto de Filosofia e Ciências Sociais (IFCS) da Universidade Federal do Rio de Janeiro (UFRJ). 
Outros autores que se tornariam clássicos, não apenas no Brasil, também se fizeram presentes nas páginas de DADOS, como, por exemplo, Shmuel Noah Eisenstadt, que publica, no mesmo no 4, de 1968, artigo com importante aporte teórico para o desenvolvimento da sociologia política em geral. Analisando os pressupostos desta subárea o autor afirma a necessidade de se ultrapassar a dicotomia Estado e sociedade e, portanto, de perspectivas que atribuam precedência de um ou outro polo, para se pensar na formação dinâmica de "centros" - definidos quase como esferas sociais - com dimensões simbólicas ("carismáticas") e de poder próprias. Em movimento complementar ao que identificamos no percurso da sociologia política ao longo desses anos na DADOS, o autor propõe descentrar o poder do sistema político e da dicotomia nele implicada para tomá-lo como instância constitutiva desses diversos "centros" e não somente do sistema institucional. O sociólogo israelense voltaria às páginas de DADOS depois de 32 anos com um artigo comparativo sobre o sistema político japonês (vol. 53, no 1 , 2010).

Igualmente notável é a convivência, na sociologia política tout court, de interesses sobre fenômenos brasileiros e outros, digamos, mais cosmopolitas - ainda que, como veremos adiante, a própria polaridade entre localismo e cosmopolitismo não se sustente muito neste caso, dada a preocupação e ambição teórica mais abrangente que perpassa grande parte dos artigos sobre a formação do Estado e as relações Estadosociedade no Brasil. De todo modo, interessa perceber como aparecem com frequência artigos tratando de América Latina (noㅗ 2/3, de 1967; no 13, 1976; vol. 52, 2009) ou comparações entre sociedades (vol. 58, 2015), industrialização / desenvolvimento e sistema político (nos 2/3, de 1967; no 10, 1973), ideologia política e participação social (no 4, 1968; no 7, 1970), estados socialistas (vol. 33, 1990), cidadania (vol. 43, 1999; vol. 46, 2003), por exemplo, ao lado de temas como, formação do Estado brasileiro (no 7, 1970; no 10, 1973; no 13, 1976; no 14, 1977; vol. 23, 1980; vol. 25, 1982; vol. 29, 1986), relações Estado-sociedade no Brasil (no 12, 1976; no 13, 1976; vol. 23, 1980; vol. 30, 1987; vol. 31, 1988; vol. 32, 1989), políticas públicas no Brasil (no 13, 1976; vol. 23, 1980; vol. 31, 1988; vol. 42, 1999) e transição democrática (vol. 36, 1993; vol. 38, 1995; vol. 54, 2011).

Como vimos antes (no Quadro 9), há notável concentração na autoria de artigos também na sociologia política como "campo", o que acontece, como também vimos, em todas as principais subáreas da coleção 
Sociologia em DADOS. Para uma melhor compreensão do que chamamos aqui de sociologia política tout court, que, afinal, é o fulcro do que tem sido a produção do "campo" da sociologia política na revista DADOS, selecionamos a produção de Elisa Reis como paradigmática. Não somente porque Reis é a autora com mais artigos publicados, oito ao longo de três décadas (1970-1990), com concentração na década intermediária, a de 1980, com cinco artigos publicados, número que a coloca entre aqueles que mais publicaram na revista nesses cinquenta anos. Mas também porque seus textos trazem o núcleo da proposta teórico-metodológica de uma das vertentes da sociologia política a partir do qual se configurou um diálogo muito próximo entre as subáreas da Sociologia até pelo menos os anos 1990.

De forma um tanto quanto esquemática podemos afirmar que essa proposta se apoia em três balizas fundamentais: primeira, para essa vertente da sociologia política, a formação do Estado-nacional em diferentes sociedades e períodos históricos é um recurso heurístico para a compreensão das singularidades empíricas e para a própria teorização; a segunda diz respeito ao fato de que, para cumprir a exigência anterior, a análise deve se concentrar em processos macro-históricos e, se possível, na comparação entre experiências sociais de modo a criar mecanismos de controle de generalização e imputação causal em relação às especificidades do caso em questão; por fim, o próprio Estado nacional ganha destaque como ator estratégico, entendido como concorrente das disputas sociais em jogo, e não somente como resultante delas (conforme os artigos de Elisa Reis nas edições 23, no 3, de 1980 e 25, no 3 , de 1982) $)^{4}$.

Tendo em vista esses marcos teóricos da sociologia política históricocomparada, os artigos de Elisa Reis publicados na DADOS buscam identificar os mecanismos ligados à singular trajetória da formação societária e à constituição de uma autoridade estatal no Brasil. Entre alguns aspectos decisivos da história brasileira, a autora chama a atenção em particular para a permanência da questão agrária e o legado da escravidão (vol. 32, no 3, 1989 e vol. 25, no 3, 1982). Através deles seria possível perceber como certas relações de propriedade e produção vigentes na sociedade agrária brasileira, impulsionada por redefinições da estrutura das relações de classe, sobretudo após a Abolição, interagiram com as diversas formas de atuação do Estado. Essas mudanças, segundo a socióloga, não ficaram confinadas ao circuito de retroalimentação em que Estado e sociedade se reforçavam mutuamente em 
seus "vícios", mas criaram espaços para outras orientações dos agentes que, muitas vezes à revelia das suas vontades, solapavam a dominação personalizada e tradicional da sociedade agrária, fortalecendo, em contrapartida, a legitimidade de uma dominação impessoalizada e burocratizada, centralizada na autoridade estatal.

No entanto, e a comparação com outros casos nacionais foi fundamental na relativização de certos pressupostos de análise, a formação do Estado-nação no Brasil não seguiria um processo linear equiparável ao dos países centrais. As mudanças na sociedade agrária brasileira não somente favoreceriam a centralização de uma autoridade estatal, mas as próprias formas de intervenção do Estado também poderiam ter efeitos diversos, como conclui a autora em relação ao período da Primeira República, em que a disputa entre as elites e suas constantes demandas ao Estado, sobretudo no tocante à economia, tiveram efeitos paradoxais ao reforçar os procedimentos administrativos e burocráticos. Essa solução peculiar de consolidação da autoridade em detrimento de soluções centradas em mecanismos de mercado conformou o padrão autoritário de modernização da sociedade brasileira.

O mesmo foco na dinâmica entre autoridade, formas de solidariedade e interesses de mercado encontra-se em análises sobre políticas públicas destinadas ao meio rural (no 13, 1976 e vol. 31, no 2, 1988), demonstrando como as intervenções estatais tiveram o duplo efeito de alterar o padrão de dominação local, gerando uma ideologia cívica entre os cidadãos, ao mesmo tempo em que a ideologia clientelística era transferida para a relação entre os favorecidos por aquelas políticas e as autoridades do Estado (espécie de "patronagem pública"). Portanto, a permanência de certas estruturas não seria um pressuposto da análise, mas algo a ser explicado a partir dos processos e as escolhas dos agentes em disputa.

\section{PENSAMENTO SOCIAL E POLÍTICO: AUTODESCRIÇÃO NO CAMPO DA SOCIOLOGIA POLÍTICA E DA TEORIA SOCIOLÓGICA}

Talvez valha a pena assinalar, mesmo que simplificadamente, o contraste dessa perspectiva com outra muito influente nas últimas décadas na sociologia contemporânea, também no Brasil, mas, não necessariamente, na revista DADOS. Referimo-nos à teoria da ação comunicativa de Habermas e à teoria da sociedade civil que, de certa forma, busca lhe oferecer maior concretude histórica. Como para a so- 
ciologia histórico-comparada, à qual a sociologia política de Elisa Reis está associada, as sociedades concebem distintamente, ou combinam de modo diverso, os três princípios básicos de coordenação societária a autoridade, a solidariedade e o mercado -, essas concepções e combinações diversas tendem a constituir opções históricas que, uma vez tomadas, produzem consequências que tendem a limitar as alternativas subsequentes de cada sociedade. Tais implicações podem ser identificadas graças à comparação entre os cursos de transformação de sociedades cujas opções foram distintas. Já Habermas (1984, 1987), procurando entender a modernidade ocidental sob a perspectiva dos efeitos do processo de racionalização sobre os atores sociais, afirma que a racionalidade comunicativa (solidariedade social) é um meio pelo qual a intersubjetividade pode, de um lado, reduzir as pretensões do "sistema" em estender sua lógica econômica (mercado) e burocrática (autoridade) à vida social e, de outro, expandir o espaço do mundo da vida. Ou seja, independente de quais tenham sido suas opções históricas passadas, as sociedades tenderiam a adotar os mesmos padrões universais de coordenação social, e a sociedade é apontada como o local da organização da democracia e da defesa contra os processos de burocratização e mercantilização da vida social.

Nesse sentido, poder-se-ia dizer que a sociologia histórico-comparada e a teoria da ação comunicativa são desenvolvimentos paralelos sobre o mesmo problema. E não há muita "comunicação" entre elas. Mas analiticamente verifica-se que a perspectiva histórico-comparada funciona como uma crítica às teorias sistêmicas da sociedade em geral, na qual se inclui Habermas. Aliás, amplamente criticado pelo seu suposto eurocentrismo, manifesto na sua identificação histórica da racionalidade comunicativa aos chamados movimentos sociais pós-materialistas, o mais próximo que teríamos, na teoria habermasiana, de atores sociais próprios da esfera pública. Nesse sentido, o argumento da sociologia histórica da articulação diferenciada entre aquelas dimensões sociais em cada sociedade e sua consequência para o curso histórico das sociedades se contrapõe à tese da convergência histórica das várias vias de desenvolvimento societário - de que não importariam quais tenham sido as suas opções históricas passadas, as sociedades tendem a adotar os mesmos padrões universais de coordenação.

Esta atenção às variações ocorridas no passado nas combinações das várias opções políticas, econômicas e culturais enquanto dimensãochave na modelagem do futuro das sociedades constitui, em grande 
medida, justamente o interesse básico de pesquisa de outra especialidade importante na coleção de artigos da revista DADOS, identificada como "pensamento social e político", com $12 \%$ do total de publicações da DADOS, quando considerado o cenário do "campo" da sociologia política. De fato, chama muito a atenção, nestes artigos, a preocupação com a predominância histórica de um capitalismo de Estado no Brasil e suas consequências, por exemplo, para uma noção de cidadania fortemente vinculada ao Estado. Fenômeno circunstanciado em diferentes momentos decisivos da formação moderna da sociedade brasileira, como os anos 1930, quando recursos autoritários foram intensamente mobilizados para promover o mercado e a solidariedade; ou os anos da ditadura militar, nos quais o projeto de modernização sacrificou a participação política e retardou a redistribuição social.

Mas essa também não parece ser uma idiossincrasia da DADOS. "Pensamento social e político" se apresenta como o quarto eixo temático de maior recorrência de grupos de trabalho e seminários na Anpocs, e como, de forma geral na área de sociologia, a recorrência de certos temas em seu interior (como desigualdade e violência) reverberam a preocupação com questões centrais sobre a construção do Estado-nação moderno no Brasil (Botelho, Ricupero e Brasil Jr., 2016).

É claro que a área de pensamento social e político, ao lado das preocupações mais gerais compartilhadas por diferentes especialidades das Ciências Sociais, também compreende formulações próprias ligadas à sua tradição de pesquisa, a qual, até certo ponto, pode ser identificada à trajetória intelectual nacional. Devemos esclarecer, aliás, que a nossa opção por considerar pensamento social e político como uma única especialidade decorre, mais uma vez, das dificuldades em distingui-las senão em termos disciplinares institucionais, como se o pensamento social correspondesse simplesmente à Sociologia, e o pensamento político, à Ciência Política. Mais uma vez, apesar de possíveis e mesmo inevitáveis diferenças, a prática das duas especialidades envolve trânsitos e intercâmbios comuns em termos de objetos, metodologias e preocupações muito mais significativas do que as suas possíveis idiossincrasias até o momento, de acordo com o que se pode verificar nas páginas de DADOS.

Levando em consideração a interdisciplinaridade da subárea de pensamento social e político brasileiro, a classificação dos artigos buscou associar não só a formação dos autores e a inserção disciplinar, quando 
declarada, mas também a forma pela qual cada um dos artigos se associava ou não ao movimento mais amplo do "campo" da sociologia política e às alterações identificadas no universo de publicações da revista DADOS. Como no caso das demais especialidades, porém, nos interessou pensar as relações e a dinâmica assumida por elas em relação ao conjunto que formam. E justamente por isso a classificação dos artigos proposta se justifica, na medida em que, conforme veremos, a particularidade da subárea de pensamento social e político é a de não só acompanhar de forma muito próxima as mudanças do perfil das publicações na DADOS - da predominância da sociologia política à teoria sociológica, algo não aparente nas demais subáreas -, mas a de também servir como instrumento heurístico na qualificação e explicitação dessas mudanças.

Feitas essas ressalvas, é notável como, no caso da revista DADOS, pensamento social e político brasileiro parece constituir, acima de tudo, uma espécie de "metalinguagem" de processos e tendências que ocorreram também noutras especialidades e, dentre elas, sobretudo, na sociologia política. Mais especificamente, esta área parece operar como uma (auto)descrição das mudanças do que se entendia e praticava como teoria nos cortes temporais e de relações entre as subáreas que até aqui realizamos. Até os anos 1990 o pensamento social e político brasileiro, através de sua abordagem muito específica voltada para o repertório intelectual brasileiro, buscava pensar a formação do Estado-nação em relação à sociedade que o subjazia e em perspectiva macro, mostrando como os papéis de certos atores, ideias e instituições ajudaram, de uma maneira ou de outra, a conformar esse processo. Embora esse procedimento tenha se mostrado muitas vezes arriscado ao se tentar buscar uma "essência", consubstanciada nas categorias de identidade nacional e de cultura política, as mais diversas contribuições nessa subárea foram, majoritariamente, a de investigar como interpretações do país - não só as obras, mas também documentos das mais diversas ordens - revelaram certos impasses de grande valor analítico sobre a formação do Estado-nação no Brasil.

São muitos os artigos publicados na revista DADOS que podem ser lidos nesta chave. Já nos nos 2/3, de 1967, temos: "A Teoria Política de Azevedo Amaral", de Aspásia Camargo, e "A Imaginação Políticosocial Brasileira", de Wanderley Guilherme dos Santos (IUPERJ). Nos dez anos subsequentes, temos, entre outros, "Cultura Política: Revista Teórica do Estado Novo" (no 4, 1968), de Marcus Figueiredo; “O Con- 
texto Político da Revolução de Trinta" (no 7, 1970), de autoria de Celina do Amaral M. Franco, Lúcia Lippi Oliveira e Maria Aparecida Alves Hime, todas elas, então, mestrandas no IUPERJ; e, no mesmo número, "Raízes da Imaginação Política Brasileira", um dos artigos de Wanderley Guilherme dos Santos publicados na DADOS que informariam um verdadeiro programa de pesquisa na área assumido por diferentes gerações. Fechando a década de 1970, temos ainda "A Economia de Manchester e a Sociologia Paulista" (no 18, 1978) de Richard Morse e “Elite Intelectual e Debate Político nos Anos 30" (no 22, 1979), de Lúcia Lippi Oliveira.

A década de 1980 se abre nas páginas de DADOS como aquela que, na coleção de artigos pesquisada e em relação ao conjunto que formam, talvez, seja a característica mais aguda dos artigos da área do pensamento social e político. Referimo-nos àquela espécie de "metalinguagem" de processos e tendências que ocorreram, sobretudo, na sociologia política - o que nos leva a pensar que a subárea do pensamento social e político, especialmente quando voltada para a discussão das chamadas "interpretações do Brasil", é um tipo de (auto)descrição da sociologia política como um campo, cujo movimento é crucial na definição da inteligibilidade do universo da pesquisa, como vimos argumentando.

Embora envolvam outras peças, o exemplo paradigmático a esse respeito são, sem dúvida, os artigos de José Murilo de Carvalho, maior autor da área na coleção DADOS, com oito artigos no total (conforme Quadro 4), e que, talvez, não por acaso, reivindique a importância e a atualidade de um clássico da nossa sociologia política no artigo "Em Louvor de Victor Nunes Leal" (vol. 23, no 1, 1980). Ao lado de artigos como "Seis Intepretações sobre o Brasil", de Luiz Carlos BresserPereira (vol. 25, no 3, 1982); “O Pensamento Sanitarista na Primeira República: Uma Ideologia da Construção Nacional”, de Luiz A. de Castro Santos (vol. 28, no 2, 1985); "Cidade, República e Mineiridade", de Helena Bomeny (vol. 30, no 2, 1987); “A Inteligência Brasileira à Luz da Sociologia Profética de Guerreiro Ramos", de Lúcia Lippi Oliveira, ou “O Tempo da Casa Grande", de Glaucia Villas Bôas (vol. 31, no 3, 1988); "República Brasileira: Viagem ao mesmo Lugar", de Maria Alice Rezende de Carvalho (vol. 32, no 2, 1989); "Epílogo do Romantismo" de Angela Alonso (vol. 39, no 1, 1996); José Murilo de Carvalho publicou mais cinco artigos na década de 1980: "O Brasil no Conselho de Estado: Imagem e Modelo" (vol. 25, no 3, 1982), “Victor Nunes Leal 
(In Memoriam)" e "República e Cidadanias" (vol. 28, no2, 1985), “Escravidão e Razão Nacional" (vol. 31, no 3, 1988), "Entre a Liberdade dos Antigos e a Liberdade dos Modernos: A República no Brasil" (vol. 32, no 2, 1989).

Todos eles abordando diretamente temas centrais da sociologia política como campo de uma perspectiva que, grosso modo, busca associar dimensão histórica e intepretações do Brasil no processo de construção e modernização do Estado nacional e da cidadania no país. Problemáticas ainda centrais nos outros dois artigos publicados por esse autor em DADOS nas décadas seguintes: "Mandonismo, Coronelismo, Clientelismo: Uma Discussão Conceitual" (vol. 40, no 2, 1997) e "Rui Barbosa e a Razão Clientelista" (vol. 43, no 1, 2000). Não se poderia deixar de destacar o artigo de Luiz Werneck Vianna "Americanistas e Iberistas: Uma Polêmica entre Oliveira Vianna e Tavares Bastos" (vol. 34, no 2, 1991), no qual analisa como os aportes interpretativos utilizados por esses pensadores sobre as relações entre Estado e sociedade configuram instrumentos importantes para a compreensão dos movimentos de formação da sociedade brasileira. Revelador da influência do campo da sociologia política sobre as demais subáreas é ainda a publicação do artigo do mesmo Werneck Vianna intitulado "Caminhos e Descaminhos da Revolução Passiva à Brasileira" (vol. 39, no 3, 1996), o qual, embora mantenha diálogo com as questões trazidas pela subárea de pensamento social e político brasileiro, constitui-se num ensaio de sociologia política no molde macro-histórico.

A partir dos anos 2000, em conformidade com as alterações mais gerais do universo de publicação da revista DADOS, o pensamento social e político brasileiro passou a pensar o seu próprio lugar dentro daquele novo "padrão de relações" que se configurava entre as subáreas e sem mais a proeminência do "campo" da sociologia política, especificamente da vertente macro-histórica (o que não significa que tenha desaparecido em suas ramificações). Mais uma vez, a ampla produção do pensamento social e político se torna recurso para dilemas empíricos e analíticos do presente, não mais - ou ao menos não mais majoritariamente - dentro de uma abordagem da sociologia política macro-histórica, mas se constituindo de ferramentas potencialmente heurísticas para o debate da teoria sociológica contemporânea. Exemplos dessa nova tendência são: "Linhagens do Pensamento Político Brasileiro", de Gildo Marçal Brandão (vol. 48, no 2, 2005); "Sequências de uma Sociologia Política Brasileira", de André Botelho, e "Simmel no Brasil", 
de Leopoldo Waizbort (ambos no vol. 50, no 1, 2007); “As Ideias que Fazem o Estado Andar: Imaginação Espacial, Pensamento Brasileiro e Território no Brasil Central", de João Marcelo Ehlert Maia (vol. 53, no 3, 2010); "Para uma Sociologia dos Intelectuais", de Elide Rugai Bastos e André Botelho (vol. 53, no 4, 2010); e "Donald Pierson e o Projeto do Vale do Rio São Francisco: Cientistas Sociais em Ação na Era do Desenvolvimento", de Marcos Chor Maio (vol. 56, no 2, 2013); "A Tese da Singularidade Brasileira Revisitada: Desafios Teóricos Contemporâneos", de Sergio B. F. Tavolaro (vol. 57, no 3, 2014), entre outros ${ }^{5}$.

Será que podemos pensar as mudanças entre esses dois grandes momentos indicados como diferenças de entendimento da relação entre os níveis de abstração/generalização e especificidades empíricas e do papel do pensamento social brasileiro nessa articulação? Pois, no primeiro momento parece que o pensamento social é mobilizado para considerar categorias analíticas que são informadas e informam um processo histórico determinado (muito mais voltado para as especificidades empíricas do caso brasileiro); enquanto no segundo momento o pensamento social parece constituir, acima de tudo, recurso para, através das especificidades empíricas consideradas, alcançar níveis maiores de generalização (inclusive com a pretensão de colocar problemas à teoria sociológica). A reposta à questão extrapola os objetivos deste artigo, mas fica registrada como tendo sido suscitada pela pesquisa que o originou.

\section{CONSIDERAÇÕES FINAIS}

No comentário aos dados sistematizados na coleção Sociologia de DADOS que acabamos de apresentar, a sociologia política constituiu um eixo heurístico para o entendimento das mudanças ocorridas nas páginas da revista nos últimos cinquenta anos. Notamos como sociologia política e pensamento social e político convergem para a discussão de problemas substantivos da formação do Estado-nação e das relações entre Estado e sociedade em perspectiva macro e históricocomparada. A partir dos anos 1990 a tendência das duas subáreas, nas páginas de DADOS, é se enfraquecer e pulverizar alguns temas substantivos de análise, bem como a metodologia que as orientava. A sociologia política passa a incorporar novas discussões como teoria do reconhecimento e formas transnacionais de cidadania, enquanto o pensamento social e político passa a rever o seu repertório como meio de interpelação teórica. Notamos também como a queda da sociologia 
política a partir dos anos 1990 é seguida por expressiva produção da teoria sociológica. Isso parece indicar ao menos duas coisas: primeiro, uma própria pulverização e rotinização de uma abordagem que era embora não exclusivamente - parte da identidade da sociologia política; segundo, a investigação de DADOS evidencia a alteração do papel da revista na história das Ciências Sociais, ou seja, de uma revista em que a produção de sociologia política (em sua interface com outras especialidades) era expressiva, e em que a própria produção de teoria estava implicada nas particularidades dessa subdisciplina, para um centro de produção de teoria ${ }^{6}$.

Alguns exemplos podem clarear essa mudança: no âmbito da sociologia política, os artigos de Bolivar Lamounier (1966, 2o semestre) sobre as potencialidades da análise funcionalista nessa área de pesquisa e o artigo já citado de Eisenstadt (no 4, 1968) sobre alguns pressupostos compartilhados entre a teoria sociológica e a sociologia política são indicativos da tendência em atrelar os problemas dessa subárea à própria concepção de teoria. Movimento semelhante encontramos no âmbito da subárea de teoria sociológica: o artigo de Carlos Estevam Martins (no 1,1966) é uma crítica direta ao empirismo então dominante nas Ciências Sociais brasileiras, com pouca pretensão de atingir níveis mais altos de generalização, propondo como caso de análise os estudos sobre o nacionalismo brasileiro. Essa escolha, como adverte o autor, não se deve somente a sua atualidade, mas à importância que o tema assumiu em nossa formação histórica, "desafio inarredável para todo e qualquer cientista social que faça parte dessa sociedade" (ibidem:88). Ainda no âmbito da teoria sociológica, podemos destacar os artigos referentes às classes sociais de Adam Przeworski (no 16, 1977), bem como a crítica a ele de Homero Rodolfo Saltalamacchia (vol. 21, 1979), e o artigo de Luiz Carlos Fridman sobre a teoria de Karl Polanyi (vol. 32, no 2, 1989). A publicação da sociologia do trabalho e estratificação social mostraram-se mais constantes em termos substantivos e metodológicos.

Em número recente da revista Sociologias (vol. 17, no 38, 2015), o dossiê "Tendências e desafios contemporâneos da sociologia política" reuniu uma série de balanços sobre esta área de pesquisa no Brasil e em outros contextos nacionais. Nesses textos, acentua-se o potencial teórico da sociologia política como uma área de fronteira, pois seu interesse nas bases sociais do poder e nas relações entre Estado e sociedade abre uma possibilidade de diálogo efetivo entre a Sociologia e a Ciência 
Política. No entanto, o que vem sendo notado é que, no lugar da comunicação entre as duas disciplinas, há uma crescente fragmentação, com recortes temáticos e teórico-metodológicos muito diferentes no que toca à análise da vida política. Por um lado, nos enfoques mais sociológicos, há uma concentração nos temas dos movimentos sociais e da cultura política; por outro, nas abordagens da Ciência Política, uma preocupação mais nítida com o funcionamento das instituições políticas e das políticas públicas. Através de um levantamento bibliométrico nos principais periódicos da Sociologia e da Ciência Política, Joshua Dubrow e Marta Kolczyñska (2015:94) identificaram o seguinte padrão:

percebe-se que as relações entre a sociologia e a ciência política são fracas e assimétricas exatamente em áreas fundamentais da sociologia política: democracia, participação política, sociedade civil e movimentos sociais. Na maioria dos casos, esses conceitos fundamentais encontram-se nos periódicos da ciência política, e as principais publicações das duas disciplinas não citam os trabalhos uma da outra com uma frequência que indique interdisciplinaridade.

Este quadro também já vinha sendo apontado por pesquisas realizadas sobre o Brasil, como nos dois levantamentos feitos por Botelho (2012, 2014). Talvez não seja por acaso que, neste contexto de especializações que pouco se comunicam entre si, a própria sociologia política tenha experimentado certo declínio nas últimas décadas, embora sua perspectiva de considerar o poder como constitutivo das relações sociais tenha se generalizado em praticamente todos os campos da Sociologia, como exemplifica perfeitamente o aumento do número de publicações na DADOS de estudos raciais e de gênero. As trajetórias dessas subáreas parecem muito próximas. No caso de relações raciais e de gênero esse aumento ocorre a partir dos anos 1990, principalmente no último decênio, no qual respondem, respectivamente, por $5 \%$ e $4 \%$ do total das publicações.

A agenda contemporânea da sociologia política envolve, portanto, retomar as relações entre Estado e sociedade como problema básico de pesquisa, tanto em termos teóricos quanto empíricos e históricos. Em vez da dissociação com a qual nos deparamos hoje, uma abordagem sociológica do "político" necessita de uma visão menos fragmentada, "na qual as dimensões sociais e políticas fossem contempladas de forma a aprofundar a análise dos encontros ou desencontros, dos conflitos ou da cooperação entre o ativismo civil e o Estado" (Scherer- 
Warren, 2015: 49). Como já havia apontado Botelho (2012:380), ao se deparar com a circunscrição da Sociologia aos fenômenos de socialização e da Ciência Política à vida institucional do Estado, seria fundamental fortalecer o diálogo entre essas diferentes dimensões da realidade social e política, uma vez que,

sem uma visão integrada sobre o movimento geral da sociedade fica difícil especificar [...] tanto como as instituições se enraízam ou não através da socialização enquanto dimensão em geral privilegiada no tratamento da questão social, quanto como os sentidos da socialização são afetados e podem ser alterados através das próprias instituições.

Como observamos em relação à sociologia política que se desenha nas páginas da revista DADOS, e a partir delas, a perspectiva histórica e a preocupação teórica e reflexiva encontradas no pensamento social e político têm desempenhado papéis fundamentais para o desenvolvimento desta tradição de pesquisa. Esta aposta no diálogo entre a área de pensamento social e político e a sociologia política pode ser ampliada para pensarmos também uma agenda teórica contemporânea da sociologia política. Como observaram Botelho e Brasil Jr. (2015) a propósito, este diálogo se desdobra em duas dimensões, uma propriamente teórica e outra substantiva. Por um lado, porque a reflexão acumulada nas gerações anteriores de intérpretes e pesquisadores da sociedade brasileira veio articulando uma série de achados teóricos sobre a relação histórica entre Estado e sociedade que seria problemático simplesmente descartar. Não se trata, é claro, de ignorar as últimas inovações da sociologia política praticada no Brasil ou em outros contextos nacionais, mas de criar um espaço de comunicação entre passado e presente da disciplina como forma de ganhar perspectiva histórica e analítica para os desafios cognitivos atuais. Até porque os problemas identificados pelas gerações anteriores não desapareceram nas últimas décadas de democratização da sociedade brasileira, mesmo que tenham tido os seus sentidos profundamente alterados. Por outro, porque as próprias "interpretações do Brasil" são parte fundamental da relação entre Estado e sociedade que importa analisar. Assim, a investigação de como ideias, instituições e atores sociais interagem em momentos históricos decisivos é fundamental para uma visão mais matizada e complexa do processo de construção da cidadania no Brasil.

Certamente, a continuidade da pesquisa comparando sistematicamente os movimentos cognitivos que surpreendemos nas páginas da revis- 
ta DADOS num quadro mais amplo das Ciências Sociais permitirá qualificar o seu sentido, isto é, em que medida aqueles movimentos, especialmente no que diz respeito à sociologia política, inovam ou acompanham tendências gerais, expressam uma particularidade ou processos mais amplos compartilhados. Isso exigiria, porém, novos desdobramentos analíticos que ultrapassam os nossos objetivos atuais, mas entendemos que, sem o percurso realizado até aqui, a questão sequer faria sentido. Como bem observou Lee Sigelman no centésimo - e comemorativo - número de The American Political Science Review, publicado em novembro de 2006, não são mesmo simples as relações entre "interno" e "externo" numa revista. Em todo caso, porém, gostaríamos de compartilhar com os leitores do artigo nossa sensação de que há uma lição importante a ser apreendida nas páginas de DADOS também sobre os problemas que vivemos atualmente: justamente no modo como os seus autores souberam aliar, em grande medida, interesse prioritário pelos problemas sociais e políticos brasileiros à imaginação de novos instrumentos de análise. $\mathrm{O}$ resultado expressivo dessa aliança problematiza, inclusive, versões convencionais sobre a objetividade das Ciências Sociais ou mesmo aquelas que consideram que o sentido de premência assumido pelos dramáticos problemas sociais e políticos em nossa sociedade seria, até certo ponto, incompatível com o esforço mais sistemático de formalização teórica verificado em países centrais. Que venham, então, os próximos cinquenta anos de DADOS.

(Recebido para publicação 10 de agosto de 2016)

(Reapresentado em outubro de 2016) (Aprovado 8 de janeiro de 2017) 


\section{NOTAS}

1. Como veremos adiante, esse número oscila entre 359 e 369, dependendo da contagem da interface da sociologia política com a área da Ciência Política. É preciso advertir que a periodicidade da publicação da revista é instável durante os dez primeiros anos, profissionalizando-se e ganhando regularidade a partir de 1976.

2. Certamente, o fato de DADOS ser um periódico científico constitui variável crucial na modelagem do universo pesquisado, e seria interessante levar em conta, mais do que pudemos fazer neste artigo, como, por exemplo, a política e o escopo editorial, suas normas de publicação, composição do corpo editorial e do comitê consultivo etc. afetam esse universo. Na mesma direção, talvez seja possível estabelecer relação entre a especialização/diversificação temática que constatamos e o reconhecimento e protagonismo que a revista vai assumindo no cenário nacional ao longo dos anos. Ótimas indicações a esse respeito são encontradas em Bringel (2016).

3. Como se verá, a unidade selecionada é menos a década de publicação e mais a publicação de DADOS na década, pois nos interessa considerar a publicação contextualizada. Esse formato nos permite localizar temas, proposições e percursos disciplinares em diálogo com a marcação temporal mais comumente utilizada pela bibliografia especializada na história das Ciências Sociais brasileiras. Além disso, buscaremos compor um quadro mais abrangente possível, de modo a captar os movimentos cognitivos de uma produção cada vez mais complexa.

4. Quando tomamos os artigos de Elisa Reis como exemplos da sociologia tout court o fazemos porque sua produção, extensa na produção da revista DADOS, condensa algumas de suas características fundamentais (sem com isso querer reduzir a abordagem da autora no contexto de produção da sociologia política). Assim vemos, por exemplo, autores em perspectiva muito próxima analisarem questões relativas ao mundo agrário, como o já citado artigo de Maria Sylvia Carvalho Franco (no 6, 1968), Amaury de Souza (no 10, 1973), Otávio Velho (no 13, 1976), Gentil Martins Dias (no 15, 1977), Victor Nunes Leal (vol. 23, no 1, 1980); e o da formação do Estado, como os artigos de Fernando José Leite Costa (no 7, 1970), Simon Schwartzman (no 10, 1973), Aspásia Camargo (no 12, 1976), Fernando Uricoechea (no 14, 1977 e no 15, 1977), José Murilo de Carvalho (no 21, 1979).

5. A interseção entre o pensamento social e político brasileiro e a área de teoria política parece guardar semelhanças com o que identificamos aqui em relação à teoria sociológica. É o que nos indicam alguns exemplos: "Por que Pensamento e não Teoria? A Imaginação Político-Social Brasileira e o Fantasma da Condição Periférica (1880-1970)", de Christian Lynch (vol. 56, no 4, 2013) e "A Poliarquia Brasileira e a Reforma Política: Análise de uma Contribuição de Wanderley Guilherme dos Santos à Teoria Política", de Marcelo Sevaybricker Moreira (vol. 57, no 12, 2014).

6. Essas indicações apontam, ademais, que as Ciências Sociais desenvolvidas no Rio de Janeiro, sobretudo quando comparadas às de São Paulo, não foram sugadas pela força gravitacional do poder estatal alijando delas sistematicidade e profissionalização, como sugerem algumas análises da história das Ciências Sociais no Brasil (Miceli, 2009). A questão, a nosso ver, é como certas especificidades relacionadas, no caso do Rio de Janeiro, à institucionalização da área e da formação de redes de pesquisa e pesquisadores não limitaram, mas o contrário, ampliaram o alcance de suas formulações e proposições teóricas. As sociologias políticas desenhadas nas páginas da DADOS exemplificam claramente isso. 


\section{REFERÊNCIAS BIBLIOGRÁFICAS}

BASTOS, Élide Rugai; BOTELHO, André. (2010), “Horizontes das Ciências Sociais: Pensamento Social Brasileiro", in C. B. Martins; H. H. T. de Souza Martins (orgs.), Horizontes das Ciências Sociais no Brasil. São Paulo, Anpocs, vol. 1, pp. 475-496.

BOTELHO, André. (2006), “Pensamento Brasileiro e Reflexividade Social (questões de pesquisa)", in M. S. G. Porto; T. Dwyer (orgs.), Sociologia em Transformação: Pesquisa Social no Século XXI. Porto Alegre, Tomo Editorial, pp. 77-86.

. (2007), "Sequências de uma Sociologia Política Brasileira". DADOS - Revista de Ciências Sociais, vol. 50, no 1, pp. 48-82.

. (2012), "Sobre as Teses do Iuperj: Ciências Sociais e Construção Democrática no Brasil Contemporâneo", in R. Barbosa Filho; F. Perlatto (orgs.), Uma Sociologia Indignada: Diálogos com Luiz Werneck Vianna. Juiz de Fora, Ed. UFJF.

. (2013), “Teoria e História na Sociologia Brasileira: A Crítica de Maria Sylvia de Carvalho Franco". Lua Nova, no 90, pp. 331-366.

. (2014), "Political Sociology: State-society Relations". Current Sociology, vol. 62, no 6, pp. 868-885.

. (2015), "Un Programa Fuerte para el Pensamiento Social Brasileño". Prismas Revista de Historia Intelectual, vol. 19, no 1, pp. 151-161.

; BRASIL JR., Antonio. (2015), Pensamento Social e Sociologia Política: Uma Agenda de Pesquisa Reflexiva. Mimeo.

BOTELHO, André; CARVALHO, Lucas C. (2011), “A Sociedade em Movimento: Dimensões da Mudança na Sociologia de Maria Isaura Pereira de Queiroz". Sociedade e Estado, vol. 26, no 2, pp. 209-238.

BOTELHO, André; RICUPERO, Bernardo; BRASIL Jr., Antonio da Silveira. (2016). Cosmopolitismo e Localismo nas Ciências Sociais Brasileiras. Trabalho apresentado no 40 Encontro Anual da Anpocs, 24-28 de outubro, Caxambu.

BRINGEL, Breno. (2016), "Nota Editorial: Política e Fluxo Editorial da DADOS". DADOS - Revista de Ciências Sociais, vol. 59, no 2, pp. 311-321.

CAMPOS, Luiz Augusto; FERES Jr., João; GUARNIERI, Fernando. (2016), “50 Anos da Revista DADOS: Uma Análise Bibliométrica do seu Perfil Disciplinar e Temático". DADOS - Revista de Ciências Sociais, vol. 59, número especial.

CARVALHO, Lucas Correia. (2015), Projeto, Conhecimento e Reflexividade: Estudos Rurais e Questão Agrária no Brasil dos Anos 1970. Tese (Doutorado em Sociologia). Programa de Pós-Graduação em Sociologia e Antropologia (PPGSA/IFCS)/UFRJ, Rio de Janeiro.

DUBROW, Joshua Kjerulf; Kolczyñska, Marta. (2015), “A Quem Pertence o Estudo da Democracia? Sociologia, Ciência Política e a Promessa da Interdisciplinaridade na Sociologia Política desde 1945". Sociologias, vol. 17, no 38, pp. 92-120.

FOUCAULT, Michel. (1975), Surveiller et Punir. Naissance de la Prison. Paris, Gallimard. . (1979), Microfísica do Poder. Rio de Janeiro, Graal. 
FRANCO, Maria Sylvia de Carvalho. (1968), “O Código do Sertão: Um Estudo sobre Violência no Meio Rural". DADOS - Revista de Ciências Sociais, no 5, pp. 22-56.

GIDDENS, Anthony. (1971), Capitalism and Modern Social Theory: An Analysis of the Writings of Marx, Durkheim and Max Weber. Cambridge, Cambridge University Press.

__ (1998), Política, Sociologia e Teoria Social. São Paulo, Editora da Unesp.

HABERMAS, Jürgen. (1984), The Theory of Communicative Action. Reason and the Rationalizalion of Society. Boston, Beacon Press, vol 1.

. (1987), The Theory of Communicative Action. Lifeworld and System: A Critique of Functionalist Reason. Boston, Beacon Press, vol. 2.

HOELZ, Mauricio. (2010), Homens Livres, Mundo Privado. Violência e Pessoalização numa Sequência Sociológica. Dissertação (Mestrado em Sociologia), Programa de Pós-graduação em Sociologia e Antropologia (PPGSA/IFCS) /UFRJ, Rio de Janeiro.

JANOSKI, Thomas et al. (eds.). (2005), The Handbook of Political Sociology. Cambridge, Cambridge University Press.

LAMOUNIER, Bolívar. (1982), “A Ciência Política no Brasil: Roteiro para um Balanço Crítico", in B. Lamounier (org.), A Ciência Política nos Anos 80. Brasília, Editora da UnB.

LUHMANN, Niklas. (1996), La Ciencia de la Sociedad. México, Universidad Iberoamericana, Anthropos, ITESO.

. (2007), La Sociedad de la Sociedad. México, Universidad Iberoamericana, Herder.

LUKES, Steven. (1972), Emile Durkheim: His Life and Work. A Historical and Critical Study. Hamondsworth, England, Penguin.

. (1974), Power: A Radical View. London, Macmillan.

LYNCH, Christian Edward Cyril. (2016), "Entre a 'Velha' e a 'Nova' Ciência Política: Continuidade e Renovação Acadêmica na Primeira Década da Revista DADOS (1966-1976)". DADOS - Revista de Ciências Sociais, vol. 59, número especial.

MAIA, João Marcelo et al. (2016), ANPOCS 40 Anos: Um Perfil Institucional. Trabalho apresentado no 40 Encontro Anual da Anpocs, 24-28 de outubro, Caxambu.

MARTINS, Carlos Estevam. (1966), “Construção de Teoria na Ciência Social Brasileira”. DADOS - Revista de Ciências Sociais, no 1, pp. 84-114.

MICELI, Sergio (org.). (2009), História das Ciências Sociais no Brasil. São Paulo, Vértice/Idesp/Finep.

REIS, Elisa Pereira. (1999), “Os Velhos e os Novos Desafios da Sociologia Política”, in J. V. T. Santos (ed.), A Sociologia para o Século XXI. Pelotas, Universidade Católica de Pelotas; Sociedade Brasileira de Sociologia, pp. 59-75.

SARTORI, Giovanni. (1969), "From the Sociology of Politics to Political Sociology", in S. M. Lipset (ed.), Politics and Social Sciences. Oxford, Oxford University Press.

SCHERER-WARREN, Ilse. (2015), “Desafios para uma Sociologia Política Brasileira: Os Elos entre Movimentos e Instituições". Sociologias, vol. 17, no 38, pp. 44-62. 
SIGELMAN, Lee. (2006), "Introduction to the Centennial Issue". The American Political Science Review, Thematic Issue on the Evolution of Political Science, in Recognition of the Centennial of the Review, vol. 100, no 4, p. V-XVI.

SOARES, Gláucio Ary Dillon. (1978), “Depois do Milagre”. DADOS - Revista de Ciências Sociais, no 19, pp. 3-26.

VIANNA, Luiz Werneck. (1999), “Weber e a Interpretação do Brasil”, in J. Souza (org.), O Malandro e o Protestante. A Tese Weberiana e a Singularidade Cultural Brasileira. Brasília, Editora da UnB, pp. 173-193. 


\section{RESUMO}

A Sociologia e a Sociologia Politica em DADOS

O artigo identifica e discute alguns movimentos cognitivos cruciais da coleção Sociologia da revista DADOS. Inspirada em ideias sobre a dinâmica da diferenciação funcional da sociologia de Niklas Luhmann como uma chave geral de leitura dos dados da pesquisa, sugere o papel central que a sociologia política, especialidade mais recorrente, tem na coleção. Ela protagoniza um movimento simultâneo de diferenciação em relação ao conjunto dos artigos publicados e de modificação desse ambiente, pelas ressonâncias que vai imprimindo nas outras especialidades da sociologia. Nessa mesma chave, sugere o papel de autodescrição reflexiva em relação ao conjunto da coleção assumido pelo pensamento social e político, a segunda especialidade mais recorrente nesses 50 anos de publicação da revista.

Palavras-chave: DADOS - Revista de Ciências Sociais; sociologia política; história das ciências sociais; pensamento social e político; Niklas Luhmann

\section{ABSTRACT \\ Sociology and Political Sociology in DADOS Journal}

This article identifies and discusses several cognitive movements that are fundamental to DADOS journal sociology collection. Employing ideas on the dynamic of functional differentiation in the sociology of Niklas Luhmann as a general means of reading the survey data reveals the central role played by political sociology in the collection, which is the most common field of specialization. The discipline leads a movement which both differentiates itself from the rest of the articles published while altering the sphere, due to the resonances it imprints on the other specialist fields within sociology. Such a reading also highlights the role played in the collection by the reflexive self-description practiced by social and political thought, which has served as the second most common field of specialization over the 50 years since the journal's first publication.

Keywords: DADOS - Revista de Ciências Sociais; political sociology; history of social sciences; political and social thought; Niklas Luhmann 


\section{RÉSUMÉ}

\section{La Sociologie et la Sociologie Politique dans DADOS}

L'article identifie et analyse certains mouvements cognitifs cruciaux de la collection Sociologie de la revue DADOS. En s'inspirant des idées sur la dynamique de la différenciation fonctionnelle de la sociologie de Niklas Luhmann comme grille de lecture des données de la recherche, on a identifié le rôle central joué par la sociologie politique dans la collection, où c'est d'ailleurs la spécialité la plus récurrente. Cette discipline est à la base d'un mouvement simultané de différenciation par rapport à l'ensemble des articles publiés, ainsi que d'une modification de cet environnement grâce aux résonnances qu'elle imprime aux autres spécialités de la sociologie. Selon cette même grille de lecture, on a pu analyser dans l'ensemble de la collection le rôle que joue l'auto-description réflexive dans la pensée sociale et politique, à savoir la seconde spécialité la plus présente dans la revue.

Mots-clés : DADOS - Revista de Ciências Sociais; sociologie politique; histoire des sciences sociales; Pensée sociale et politique; Niklas Luhmann

\section{RESUMEN}

\section{La Sociología y la Sociología Política en DADOS}

El artículo identifica y discute algunos movimientos cognitivos cruciales de la colección Sociología de la revista DADOS. Inspirada en ideas sobre la dinámica de la diferenciación funcional de la sociología de Niklas Luhmann como clave general de lectura de los datos de la investigación, sugiere el rol central que tiene la sociología política - especialidad más recurrente - en la colección. Ella protagoniza un movimiento simultáneo de diferenciación frente al conjunto de los artículos publicados y de modificación de ese ambiente, debido a las resonancias que imprime en las demás especialidades de la sociología. En esa misma clave, sugiere el rol de la autodescripción reflexiva frente al conjunto de la colección asumido por el pensamiento social y político, segunda especialidad más recurrente en los 50 años de publicación de la revista.

Palabras clave: DADOS - Revista de Ciências Sociais; Sociología política; historia de las Ciencias Sociales; pensamiento social y político; Niklas Luhmann 